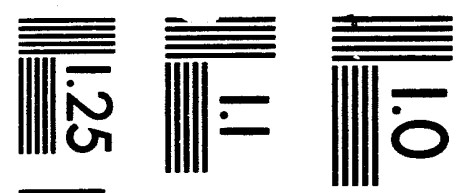

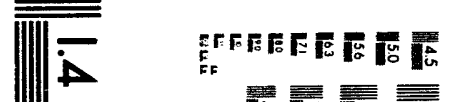

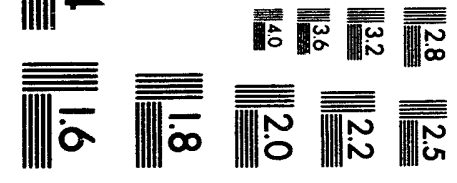



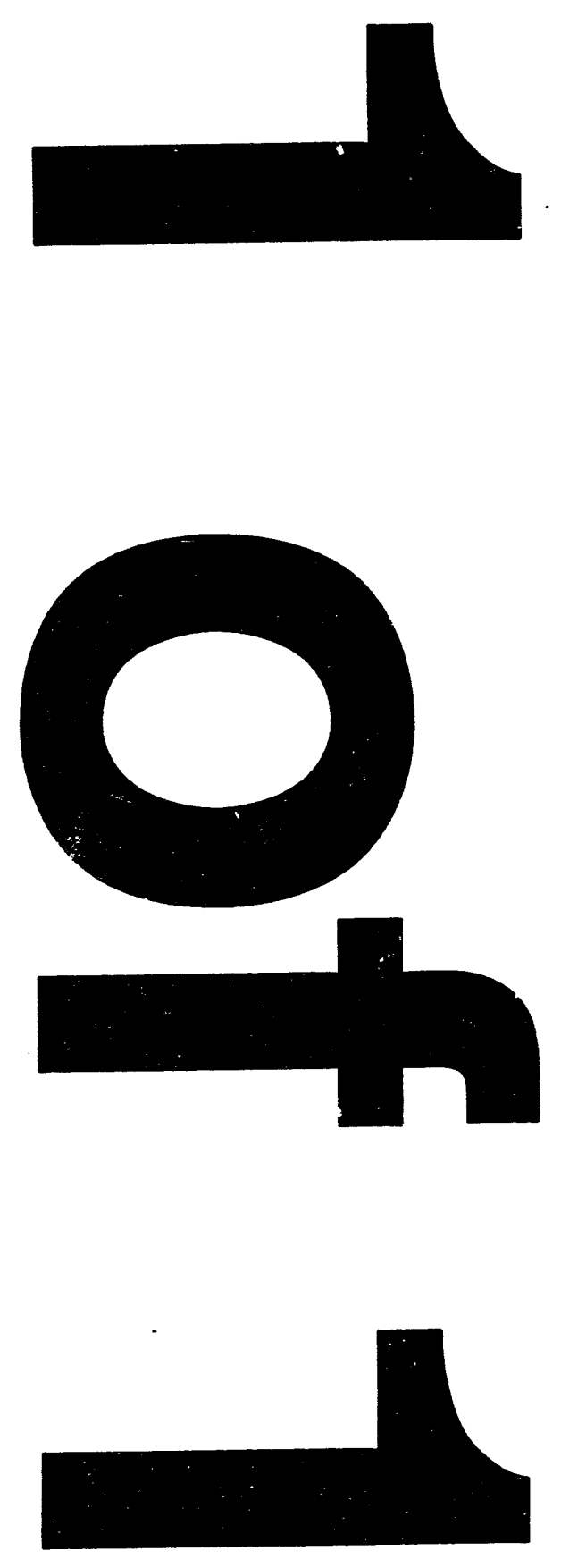


\section{Pesert
research
institute}

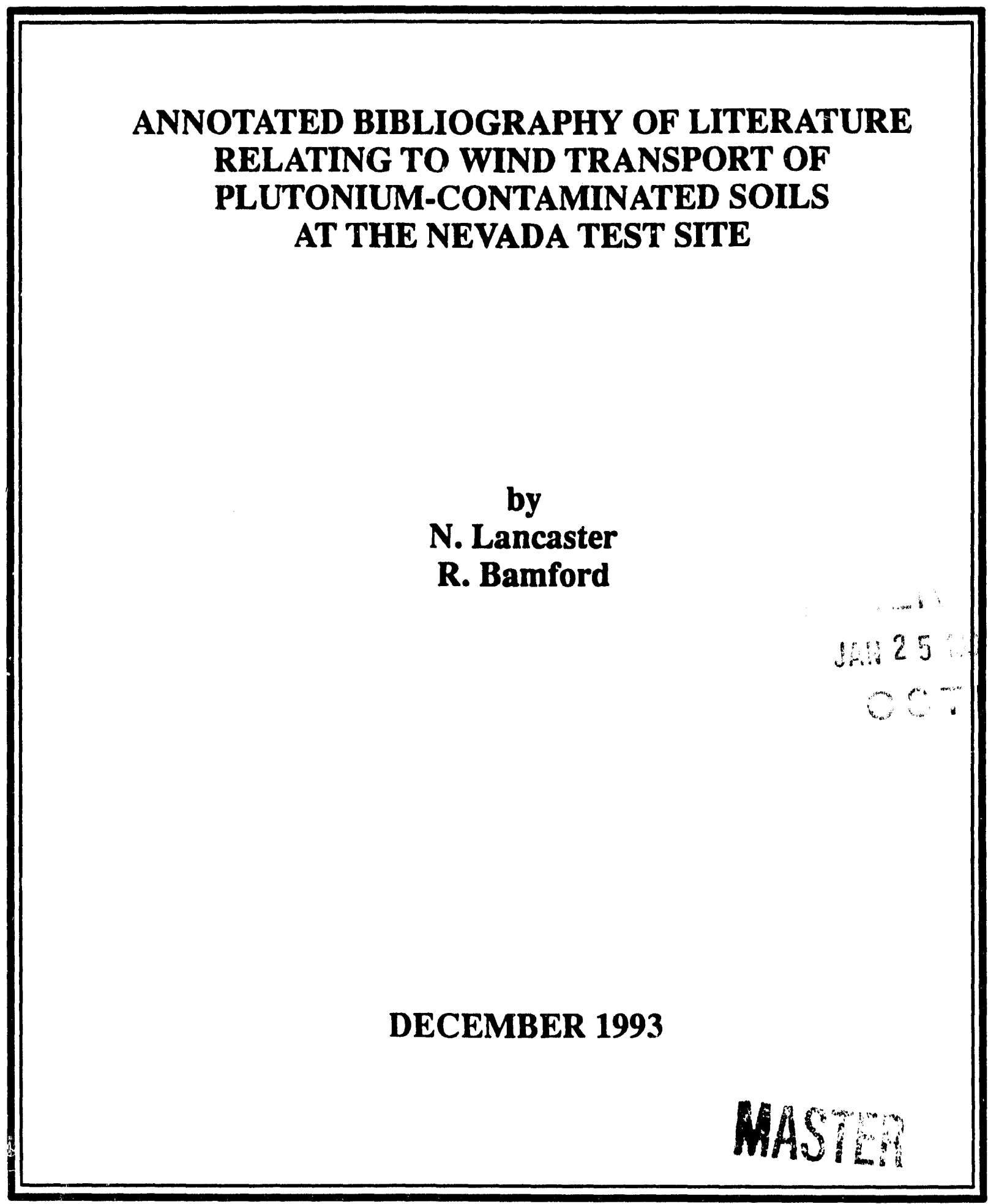

\section{QUATERNARY SCIENCES CENTER}




\title{
ANNOTATED BIBLIOGRAPHY OF LITERATURE RELATING TO WIND TRANSPORT OF PLUTONIUM-CONTAMINATED SOILS AT THE NEVADA TEST SITE
}

\author{
by \\ N. Lancaster \\ R. Bamford
}

DECEMBER 1993

QUATERNARY SCIENCES CENTER 
This report was prepared as an account of work sponsored by the United States Government. Neither the United States nor the United States Department of Energy, nor any of their employees, makes any warranty, express or implied, or assumes any legal liability or responsibility for the accuracy, completeness or usefulness of any information, apparatus, product or process disclosed, or represents that its use would not infringe privately owned rights. Reference herein to any specific commercial product, process, or service by trade name, mark, manufacturer, or otherwise, does not necessarily constitute or imply its endorsement, recommendation, or favoring by the United States Government or any agency thereof. The views and opinions of authors expressed herein do not necessarily state or reflect those of the United States Government or any agency thereof.

This report has been reproduced directly from the best available copy.

Available to DOE and DOE contractors from the Office of Scientific and Technical Information, P.O. Box 62, Oak Ridge, TN 37831; prices available from (615) 576-8401.

Available to the public from the National Technical Information Service, U.S. Department of Commerce, 5285 Port Royal Rd., Springfield, VA 22161. 


\title{
ANNOTATED BIBLIOGRAPHY OF LITERATURE RELATING TO WIND TRANSPORT OF PLUTONIUM-CONTAMINATED SOILS AT THE NEVADA TEST SITE
}

\author{
by \\ N. Lancaster \\ R. Bamford
}

DECEMBER 1993

QUATERNARY SCIENCES CENTER 


\title{
ANNOTATED BIBLIOGRAPHY OF LITERATURE RELATING TO WIND TRANSPORT OF PLUTONIUM-CONTAMINATED SOILS AT THE NEVADA TEST SITE
}

\author{
by \\ N. Lancaster \\ R. Bamford \\ Quaternary Sciences Center \\ Desert Research Institute \\ University and Community College System of Nevada \\ prepared for \\ Nevada Operations Office \\ U.S. Department of Energy \\ Las Vegas, Nevada
}

December 1993

The work upon which this report is based was supported by the U.S. Department of Energy under Contract \#DE-AC08-90NV10845. 


\section{INTRODUCTION}

During the period from 1954 through 1963, a number of tests were conducted on the Nevada Test Site (NTS) and Tonopah Test Range (TTR) to determine the safety of nuclear devices with respect to storage, handling, transport, and accidents. These tests were referred to as "safety shots." "Safety" in this context meant "safety against fission reaction." The safety tests were comprised of chemical high explosive detonations with components of nuclear devices. The conduct of these tests resulted in the dispersion of plutonium, and some americium over areas ranging from several tens to several hundreds of hectares.

Of the various locations used for safety tests, the site referred to as "Plutonium Valley" was subject to a significant amount of plutonium contamination. Plutonium Valley is located in Area 11 on the eastern boundary of the NTS at an elevation of about $1,036 \mathrm{~m}(3,400 \mathrm{ft})$. Plutonium Valley was the location of four safety tests (A, B, C, and D) conducted during 1956.

A major environmental, health, and safety concern is the potential for inhalation of $\mathrm{Pu}^{239,240}$ by humans as a result of airborne dust containing $\mathrm{Pu}$ particles. Thus, the wind transport of $\mathrm{Pu}^{239,240}$ particles has been the subject of considerable research.

This annotated bibliography was created as a reference guide to assist in the better understanding of the environmental characteristics of Plutonium Valley, the safety tests performed there, the processes and variables involved with the wind transport of dust, and as an overview of proposed clean-up procedures. 


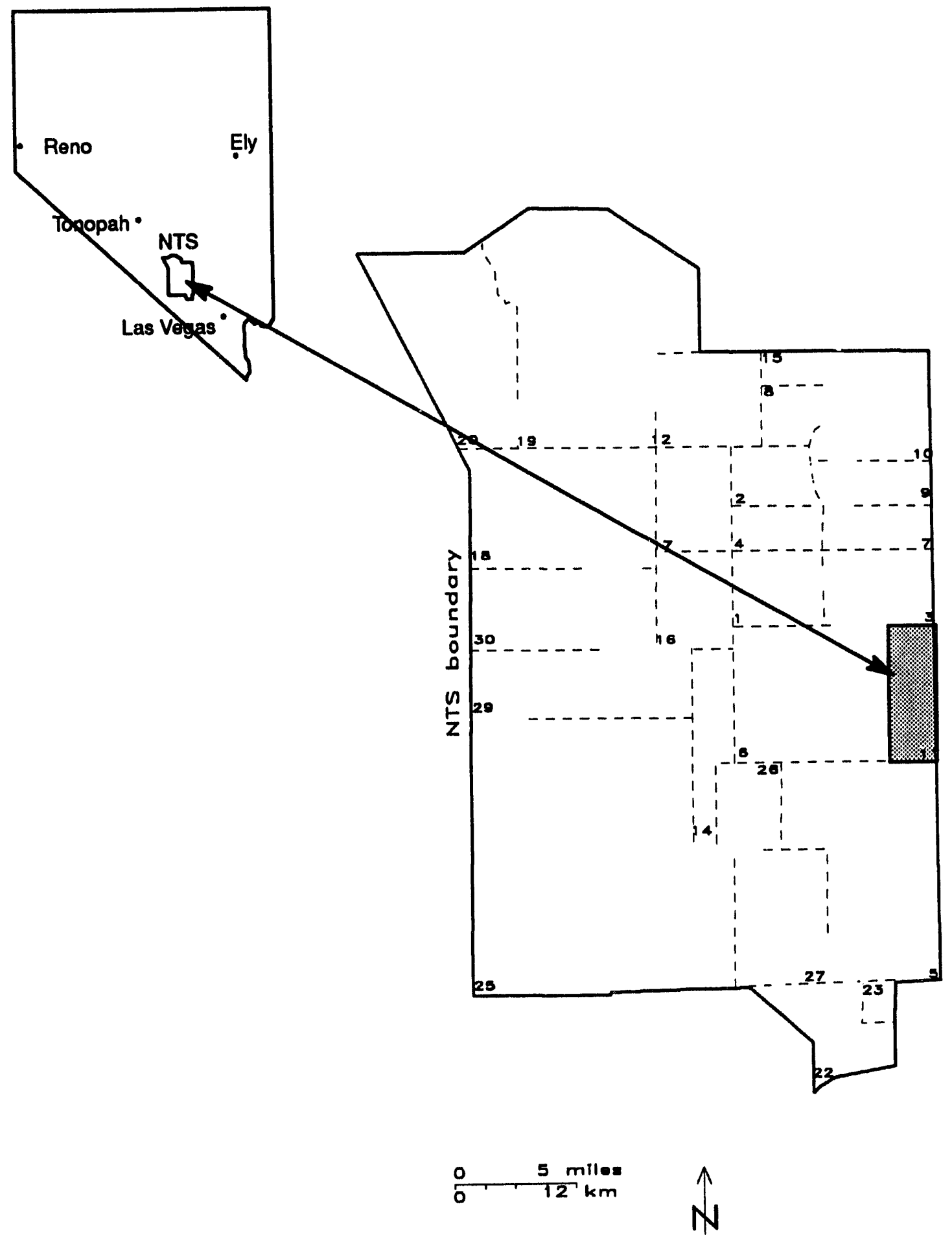

Figure 1. Shaded area indicates Area 11 on the Nevada Test Site. 
1. (1971). Proceedings of Environmental Plutonium Symposium, August 4-5, 1971, Los Alamos Scientific Laboratory, University of California, Los Alamos, New Mexico. National Technical Information Service, U.S. Department of Commerce, Springfield, Virginia.

This document contains the reports of a symposium to discuss the distribution and measurement of plutonium in the environment. The range of topics consists primarily of three categories. The first category deals with the introduction and distribution of plutonium into the environment, the second category discusses methods of sampling and analyzing environmental samples and the third investigates the results and conclusions that may be inferred from data.

2. (1974). NVO-153: The Radioecology of Plutonium and Other Transuranics in Desert Environments. Nevada Operations Office, U.S. Atomic Energy Commission, Las Vegas, Nevada.

This progress report documents activities of the various components of the Nevada Applied Ecology Group (NAEG). Reports cover research on the radioecology of plutonium at the Nevada Test Site (NTS) regarding soils, vegetation, large and small vertebrates, microorganisms, resuspension, distribution and inventory, decontamination procedures, statistics, and support activities.

3. (1974). NVO-142: The Dynamics of Plutonium in Desert Environments. Nevada Operations Office, U.S. Atomic Energy Commission, Las Vegas, Nevada.

This document is a Nevada Applied Ecology Group Progress Report for July 1974 regarding the dynamics of plutonium in desert environments. Reports discuss plutonium regarding soils, vegetation, microorganisms, animals, resuspension, statistics, distribution, and inventory.

4. (1974). CONF-740921. Atmosphere-Surface Exchange of Particulate and Gaseous Pollutants. Technical Information Center, Energy Research and Development Administration, Richland, Washington.

The combined papers in this proceedings document the state-of-the-art of deposition and resuspension. The 58 papers are almost evenly divided between deposition and resuspension. Participants, including representatives of six foreign countries, reported research results from universities, state and Federal government organizations, and government contractors.

This was the first symposium devoted solely to the atmosphere-surface exchange of particulates and gaseous pollutants by dry deposition and resuspension. The symposium was concerned with solving two interdisciplinary problems. One aim was to encourage reporting research results in such a way that they might serve as suitable boundary conditions for all disciplines. The other purpose of the symposium was to publish a state-of-the-art reference book to stimulate research toward solving unresolved problems.

5. (1976). NVO-159: Studies of Environmental Plutonium and Other Transuranics in Desert Ecosystems. NAEG Workshop Session, May 1975, Las Vegas, Nevada, Nevada Applied Ecology Group.

This document is comprised of summary progress reports of investigations and support activities of the NAEG, Nevada Operations Office, funded by the Division of Military Application, Headquarters, Energy Research and Development Administration (ERDA). 
Essentially, the NAEG investigators have provided an update of various environmental studies currently in progress at the NTS. The investigations are part of an integrated research program designed to: provide information on the movement of plutonium and other radionuclides in the environment of NTS; predict any possible associated hazard to man; and recommend related cleanup and treatment, if required, for radioactively contaminated areas.

Topics discussed include: soils, vegetation, animals, microorganisms, distribution, inventory, statistics.

6. (1976). NVO-166: Selected Articles of the NAEG Procedures Handbook for Environmental Transuranics. Nevada Applied Ecology Group Procedures Handbook for Environmental Transuranics, Energy Research and Development Administration, Las Vegas, Nevada.

These articles concentrate on field procedures for transuranics in the desert environments. Articles describe methods for proper collection, choosing sampling locations, and for recording the characteristics of plutonium in statistically accurate manners.

7. (1976). Transuranium Nuclides in the Environment. Transuranium Nuclides in the Environment, San Francisco, International Atomic Energy Agency, Vienna.

The purpose of this symposium was to address the problem areas related to the hazards of plutonium: its movement in the biosphere, its measurement and concentrations in various life forms, and its effects on man himself. Areas covered include Ecological Studies, Effluents and Marine Studies, Geohydrologic Studies, Biologic Uptake and Transfer, Pathways to Man, Environmental Monitoring, Health Effects, Risks, Standards, and Evaluation of Environmental Materials.

8. (1977). Final Environment Impact Statement: Nevada Test Site, Nye County, Nevada. Energy Research and Development Administration.

This report gives a specific overview of the Nevada Test Site. The report begins by describing the regulations of past and present nuclear testing. The proximity of test site locations to populated areas is discussed. Specifically, the document describes the radiological environment of the test site, its topography, climate, meteorology, geology, soils, surface waters, vegetation, microorganisms, and animals. The types of vegetation, microorganisms, and animals are specifically identified. The report concludes by discussing external exposure levels and the physical changes induced upon the topography by nuclear testing.

9. (1977). NVO-181: Transuranics in Desert Ecosystems, Nevada Applied Ecology Group, November 1977. U.S. Department of Energy, Nevada Operations Office, Las Vegas, Nevada.

The annual Plutonium Information Conference of the NAEG was held March 1977 in Las Vegas, Nevada. This document contains the research reports presented at the conference. Some of the presentations at this conference included safety-shot study findings, and attempts to synthesize the 10 NAEG safety-shot study areas in desert environments. Other reports include refinement of estimates of inventory in surface soil or safety-shot sites. Overall, the reports discuss ispics including vegetation, soils, distribution and inventory, small and large animals, and statistical information. 
10. (1977). NVO-178: Transuranics in Natural Environments - A Symposium at Gatlinburg, Tennessee, October 1976. Nevada Applied Ecology Group, Energy Research and Development Administration, Las Vegas, Nevada.

The NAEG Symposium on the Dynamics of Transuranics in Terrestrial and Aquatic Environments was held in October 1976 at Gatlinburg, Tennessee. The symposium was planned to bring about a concerted review and evaluation of the current status of a major environmental problem and the associated body of information available to investigators involved in studies of environmental transuranics. Topics reviewed are historical review, soils research, microorganism research, resuspension and particle research, vegetation research, animal research, field and laboratory studies, transuranic research in aquatic environments, statistics, and modeling.

11. (1977). NVO-171: Environmental Plutonium on the Nevada Test Site and Environs. Nevada Applied Ecology Group Annual Information Conference, Las Vegas, Nevada, Nevada Applied Ecology Group.

This document is the compilation of research reports presented at the NAEG annual information conference and addresses issues of the following NAEG objectives: 1) delineate locations of contamination; 2) determine concentration in ecosystem components; 3) quantify rates of movement among ecosystem components; 4) evaluate radiological hazards of plutonium; 5) identify areas which need to be cleaned up or treated; and 6) develop techniques for cleanup or treatment.

12. (1977). Environmental Research on Actinide Elements. Symposium on Environmental Research on Actinide Elements, Hilton Head, South Carolina, Office of Scientific and Technical Information, U.S. Department of Energy.

The papers contained in this volume were invited presentations organized by the Department of Energy's Office of Health and Environmental Research (OHER). The purpose of the symposium was to synthesize the results of OHER-sponsored research conducted during the late 1970s and early 1980s on the behavior of transuranic and actinide elements in the environment. Topics included are: Environmental Chemistry of Actinide Elements, Environmental Research on Actinide Elements in Terrestrial Ecosystems, and Environmental Research on Actinide Elements in Aquatic and Marine Ecosystems.

13. (1978). NVO-192: Selected Environmental Plutonium Reports of the NAEG, June 1978. U.S. Department of Energy, Las Vegas, Nevada.

On February 28 through March 2, 1978, the Annual Plutonium Information Conference was held in San Diego by the Nevada Applied Ecology Group (NAEG). The presentations by the NAEG research groups are primarily summarization reports. These presentations investigate issues of plutonium regarding small and large animals, microorganisms, plant-soil studies, Reynolds Electrical and Engineering Company (REECo) support, sample analysis reports, statistics and modeling, particle studies, and contributed papers.

14. (1980). Transuranic Elements in the Environment. National Technical Information Service, U.S. Department of Commerce, Springfield, Virginia.

This is a summary of environmental research on transuranium radionuclides funded by the U.S. Department of Energy through calendar year 1979. 
The objectives of this book are to assemble the available information on the behavior of transuranic nuclides in the environment following their release from a variety of source terms, their translocation by physical and biological transport phenomena, and the interpretation of the consequences of such concentrations as inight be found in higher trophic levels of food webs. The authors discuss both similarities and differences in transuranic nuclide behavior in various environmental settings and identif:' research needs as they perceive them.

15. (1985). NVO-272: The Dynamics of Transuranics and Other Radionuclides in Natural Environments. U.S. Department of Energy, Nevada Operations Office, Las Vegas, Nevada.

The Plutonium Information Conference of the Nevada Applied Ecology Group was held June 28-30, 1983, at the Marina Hotel in Las Vegas, Nevada. This document contains the research reports presented at the conference. It primarily deals with plutonium resultant from nonsafety-shot applications. The reports cover plutonium-related topics of distribution and inventory, vegetation, soils, resuspension, small and large animals and statistics.

16. Anspaugh, L.R., J.H. Shinn and D.W. Wilson (1974). "Evaluation of the Resuspension Pathway Toward Protective Guidelines for Soil Contamination with Radioactivity." Population Dose Evaluation and Standard for Man and His Environment, International Atomic Energy Agency, Vienna, p. 513-524.

The purpose of this paper is to develop a rationale for setting protective guidelines for soil contamination based upon an evaluation of the resuspension pathway, and to discuss some of the cost-benefit aspects of the application of such guidelines. Two models, which may be used to predict the average concentration of resuspended aerosols, are developed. One model uses the time-dependent resuspension factor approach, and places emphasis on resuspension at late times. The second model is appropriate only for aged sources and uses a mass-loading approach. The relative significance of the resuspension pathway is also modelled in comparison to the initial exposure resulting from a safety-shot. Two hypothetical ${ }^{239} \mathrm{Pu}$ contamination situations are modelled. Protective guidelines for ${ }^{239} \mathrm{Pu}$ soil contamination are derived from these studies. An estimate of the biological cost of not cleaning up contaminated areas is compared with the engineering and agricultural costs of soil removal.

17. Anspaugh, L.R., J.H. Shinn, P.L. Phelps and N.C. Kennedy (1975). "Resuspension and Redistribution of Plutonium in Soils." Health Physics 29:571-582.

Formulae are derived which parameterize dust and plutonium fluxes in terms of micrometeorological and soil erodibility parameters. Specifically, the article discusses the resuspension of $239,240 \mathrm{Pu}$, and analyzes the equations available to evaluate the resuspension. Included are discussions of weathering, Pu depths in soil after deposition, and redistribution from the point source. Interim, simple models utilizing the time-dependent resuspension factor and mass-loading approaches are derived which may be used to predict the average concentration of resuspended plutonium. Measurements of the resuspension of plutonium at the NTS are summarized in terms of a resuspension rate through the use of Healy's model of transport and diffusion. Values of the resuspension rate varied from $2.7 \times 10^{-12}$ to $4.8 \times 10^{-10} \mathrm{sec}^{-1}$. The relationship between the resuspension rate and the historical resuspension factor is developed. 
18. Anspaugh, L.R., P.L. Phelps, N.C. Kennedy, J.H. Shinn and J.M. Reichman (1976). "Experimental Studies on the Resuspension of Plutonium from Aged Sources at the Nevada Test Site." Atmosphere-Surface Exchange of Particulate and Gaseous Pollutants, ERDA Symposium Series, Energy Research and Development Administration, p. 727-743.

Measurements of ${ }^{239,240} \mathrm{Pu}$ concentrations in air, distributions with particle size, and saltation fluxes at the GMX site demonstrate that the GMX site is still a significant resuspension source although the total initial release was limited to a few curies. At the center of the source, the concentrations were directly proportional to the square of the friction velocity. Healy's (1974) model of transport and diffusion was used to derive resuspension rates that varied from $2.7 \times 10^{-12}$ to $4.8 \times 10^{-10} \mathrm{sec}^{-1}$. The activity median aerodynamic diameter of the plutonium aerosol varied from 1.6 to $8 \mu \mathrm{m}$. The movement of soil in saltation was not significant.

The synthesis of the plutonium concentration measurements with parameterizations based upon fast-response measurements of dust concentrations and Healy's model of transport and diffusion resulted in a calculation of resuspension rates independent of source geometry and a normalization of resuspension rates to a micrometeorological parameter directly relatable to flux. Similar methods should apply to any aged source where an association of the contaminant with the host soil is expected.

19. Anspaugh, L.R. and P.L. Phelps (1976). "Resuspension Element Status Report, May, 1975, NAEG." Studies of Environmental Plutonium and Other Transuranics in Desert Ecosystems (NVO-159), p. 91-100.

The resuspension-inhalation pathway is generally regarded as the critical pathway for a few radionuclides of very low biological availability, such as plutorium. The primary goal of the Resuspension Element Program is to develop a general model for the prediction of the average concentration of resuspended contaminants. This report briefly summarizes past accomplishments, current studies, and future plans of the resuspension project being conducted at the NTS.

20. Anspaugh, L.R. and P.L. Phelps (1978). "Results and Data Anaiysis: Resuspension Element Status Report." P. 359-391.

REECo collected and analyzed for ${ }^{239} \mathrm{Pu}$ at the GMX safety-shot site on the Nevada Test Site. Air filter samples were collected from February 1971 to July 1972 and control samples were taken at Mercury, NTS, at Building 214 during the same period. At GMX, two stations were maintained throughout this time period. Both were located on the fence perimeter, one to the northeast and one to the southwest of ground zero.

The groups of samples which had detectable quantities of ${ }^{239} \mathrm{Pu}$ were tested to determine the statistical probability that the samples were drawn from the same source population.

The conclusion was drawn that the ${ }^{239} \mathrm{Pu}$ deposited at the GMX site more than 15 years prior to measurement still represents a significant resuspension source. At the perimeter of the fence surrounding the exclusion area, however, the average air concentration of resuspended ${ }^{239} \mathrm{Pu}$ is only a small fraction of the presently accepted maximum permissible concentration for occupational exposure. 
21. Arent, L.J. (1991). "Industrial Hygiene Monitoring for Particulate During PR5000 F] Pavement Profiler Demonstration." Memorandum - Reynolds Electrical and Engineering Co., Inc.

The purpose of this memorandum is to discuss the amount of dust created during the use of the PR5000 FL Front Loading Pavement Profiler at Yucca Flat in Area 6, south of Tweezer Road. The Profiler has been proposed as a potential tool for removing plutonium contaminated soils from the soil surface.

Air samplers were located to determine dust levels near the equipment and the equipment operators. The air monitoring included particle-size distribution, total dust, and respirable fraction sampling. The profile operations were performed with various amounts of water added to the soil to increase soil moisture to help reduce dust emissions. Weather conditions during testing were also considered.

Results are demonstrated in various tables that account for dust size, quantity of size collected, percent in size range, and the cumulative percent less than size range. Data obtained from the sampling show that the airborne particulate levels were negligible to minimal.

22. Arent, L.J. (1991). "Industrial Hygiene Monitoring for Particulates During Motor Grader and Paddle Scraper Demonstrations." Memorandum - Reynolds Electrical and Engineering Co., Inc.

In this memorandum, the dust levels of two soil removal devices are evaluated to determine their potential for employment in the removal of plutonium contaminated soil.

The demonstration was conducted at Yucca Flat in Area 6, south of Tweezer Road, approximately one mile east of Mercury Highway. Air monitoring, which included particle-size determination, total dust, and respirable fraction sampling, was conducted during the demonstration of two types of equipment: a motor grader and a paddle scraper. The motor grader operation consisted of cutting the soil with the motor grader, then removing the soil with a front end loader and a belly dump truck. The paddle scraper operation was a one-step process, the soil was cut and collected concurrently.

Air samplers were located at various locations "upwind" and "downwind" near equipment activity. Each piece of equipment was tested on dry soil and soil soaked with one inch of water and with two inches of water (six operations total). During the test runs, one air sampler collected a level of dust above the permissible exposure limit (PEL) established by the Occupational Safety Health Administration for total respirable dust. This sample was collected during very high wind conditions; the sampling pump was located downwind of the motor grader demonstration on dry soil.

23. Barnes, M.G., P. Delfiner and R.O. Gilbert (1977). "A New Statistical Tool, Kriging, and Some Applications to Area 13 Data." Transuranics in Desert Ecosystems (NVO-181), p. $431-445$.

Kriging is a statistical procedure which has proven in practice to be very realistic and to be less prone to unsatisfactory results than some common approaches. A very brief explanation to the theory behind kriging is presented, along with a discussion of the technique. A description is given of BLUEPACK, a computer program which performs kriging, and several examples illustrate some uses of kriging and the flexibility of the program. 
24. Bliss, W.A. and F.M. Jakubowski (1977). "Environmental Plutonium Levels Near the Nevada Test Site." Transuranics in Desert Ecosystems (NVO-181), p. 187-205.

This report updates results and discussions of efforts to define the plutonium distribution on the environs of the NTS. The EPA's Environmental Monitoring Systems Laboratory in Las Vegas has been engaged in these efforts since 1970 . Levels of ${ }^{239} \mathrm{Pu}$ are graphically displayed for surrounding environs and neighboring cities.

\section{Brady, D.N. (1976). "Results of Preliminary Study of Soil Mound and Desert Pavement} Vertical Profile Pairs in Area 11, NTS." (NVO-166), p. 53-57.

This article outlines the methods to measure soil mounds in desert pavement environments. Soil samples obtained from 10 soil mounds and 10 adjacent desert pavement locations near site $C$ in Area 11 at the NTS are discussed.

26. Chen, H. (1992). Resuspension of Soil in a Desert Environment. Department of Mechanical, Industrial, and Nuclear Engineering, Universitv of Cincinnati, Radiological A ssessment Group, May 6, 1992.

The resuspension of radionuclides from the soil to atmosphere has significant importance for air pollution in a desert situation. The resuspension concentration directly relates to the probability of the deposition of contaminants in the pulmonary region of the lung which is governed solely by the aerodynamic particle size of the contaminants. The author explores various models to try and predict the concentration of contaminants suspended from the surface by parameters which can be measured easily. Models reviewed are Anspaugh's Model, Slinn's Model, Reeks's Model, Wen and Kasper's Model, Braatens' Model, and the formulation of a new/hybrid model.

27. Chen, H. (1992). Calculation of Soil Loss Due to Wind Erosion Update. Health Physics Option, Department of Mechanical, Industrial, and Nuclear Engineering, University of Cincinnati, Radiological Assessment Group, May 6, 1992.

The purpose of this article is to discuss the potential for soil erosion due to the removal of vegetation from the soil surface prior to the removal of contaminated soil. Sites disturbed in this manner can suffer severe soil erosion. In this article the author estimates some results by using the data from Nevada Test Site Area 13 and compares the effects by different models and by different erosion control methods. Models investigated are Anspaugh's model and the Universal soil loss equation model for bare fields, peddle-covered fields and vegetation-covered fields. The paper concludes with a discussion of new model development.

28. Chen, H. (1992). Evaluation of Possible Parameters Affecting Wind Erosion and Soil Loss. Department of Mechanical, Industrial, and Nuclear Engineering, University of Cincinnati, Radiological Assessment Group, May 6, 1992.

The purpose of this article is to discuss the possible paraneters of wind erosion. Wind erosion is the process by which loose surface material is picked up and transported by the wind, and surface material is abraded by windborne particles. The spatial redistribution and resorting of particles by wind erosion is most severe in those areas that experience low, variable and unpredictable rainfall, high temperatures, and high rates of evaporation and high wind velocity, as is the case in Nevada deserts. The factors influencing wind erosion are numerous and involve the relationships of air, surface, climate, soil composition, and time. These relationships are investigated and explained mathematically. 
29. Chepil, W.S. and N.P. Woodruff (1963). The Physics of Wind Erosion and Its Control. Advances in Agronomy 15:211-302.

This paper discusses the physics of wind erosion and the various methods of its control. Soil particle movement is initiated when the pressure of the wind against the surface soil grains overcomes the force of gravity on the grains. The grains move along in a series of jumps known as saltation. The higher the grains jump, the more wind derived energy. The impacts of the saltating rrains initiate movement of larger and denser grains and of smaller dust particles. The severity of wind erosion depends on equilibrium conditions between soil, vegetation, and climate. Wind erosion equations are discussed to help estimate soil loss and prevent erosion.

30. Chepil, W.S. (1945). "Dynamics of Wind Erosion: 1. Nature of Movement of Soil by Wind." Soil Science 60:305-320.

The purpose of this paper is to examine the energy relationships between the air currents and soil to study the problems of wind erosion and its controls. The author discusses the complex relationships of air, ground, and soil that he believes to be the main influences of wind erosion. The phenomena of particle movement is discussed for various-sized particles.

31. Chepil, W.S. (1950). "Properties of Soil that Influence Wind Erosion: The Governing Principal of Surface Roughness.” Soil Science 69:149-162.

Wind erosion is dependent directly on the physical conditions of the soil. Differences in erodibility suggest that inherent soil properties play an important role. To better understand these relationships, the author conducted a series of studies to investigate the relationship between erodibility and the physical structure of soil. The amount of the soil erodible by the wind is limited to the critical height of and the distance between the nonerodible fractions that are exposed at the surface by the wind. Erosion ceases as soon as this critical stage is reached. The ratio of height of surface projections to the distance between projections after soil removal has ceased remains constant irrespective of the size and proportion of the nonerodible clods contained in the soil. The ratio varies with other factors such as wind velocity and size, shape, and apparent specific gravity of the erodible fractions.

32. Church, B.W., D.W. Wheeler, C.M. Campbell, R.V. Nutley and L.R. Anspaugh (1990). "Overview of the Department of Energy's Off-Site Radiation Exposure Review Project (ORERP)." Health Physics 36:503-510.

The Off-Site Radiation Exposure Review Project (ORERP) was established by the U.S. Department of Energy (DOE) to: 1) collect, preserve, and disseminate historical data related to radioactive fallout and health effects from nuclear testing; and 2) reconstruct, insofar as possible, the exposures to off-site public from nuclear testing at the Nevada Test Site and doses to individuals resulting from these exposures.

The first ORERP objective was to identify and collect historical information relating to fallout in the environs of the NTS and to make information available to the public. This was achieved by creating the Coordination and Information Center (CIC) at 3084 South Highland Drive in Las Vegas, NV. The CIC is operated by REECo for DOE. The task groups involved in dose assessment are outlined. 
33. Cline, J.F. and V.A. Uresk (1979). "Revegetation of Disturbed Grounds in the Semi-Arid Climate of Southcentral Washington." Health Physics 36:289-294.

The purpose of this paper was to test the efficacy of various soil treatments in establishing a self-sustaining vegetative cover on soil fill overlying a portion of a former radioactive waste pond. Using treatments of straw, clay and a straw/clay mixture, the soil was sufficiently stabilized to resist wind erosion. The shallow-rooted vegetation (cheatgrass), planted to impede the growth of deep-rooted radionuclide carriers, maintained itself through three growing seasons and will probably persist in the study area for several decades.

34. Cohen, B. (1986). "Poll of Radiation Health Scientists." Health Physics 50(5):639-644. A sampling of 210 university-employed radiation health scientists randomly selected from the membership lists of the Health Physics Society and the Radiation Research Society was polled in a secret ballot. The results support the position that the public's fear of radiation is substantially greater than realistic due to exaggerations by television, newspapers, and magazines. There is a pattern of the media giving the most coverage to those with the lowest credibility in the scientific community. The scientists polled believe that the amount of money now being spent on radiation protection is sufficient, and that the openness and honesty of U.S. Government agencies about dangers of radiation were way below average before 1972, but have been above average since then.

35. Cowherd, C., G.E. Muleski and J.S. Kinsey (1988). Control of Open Fugitive Dust Sources: Final Report. Midwest Research Institute.

The purpose of this document is to provide state and local regulatory personnel with sufficient information to develop control plans for open dust sources with particulate matter smaller than 10 microns in diameter. The following sources are discussed in this document: paved roads, unpaved roads, storage piles, construction/demolition activities, open area wind erosion, and agricultural tilling. Available emission factors are presented to provide a basis for analyzing the operative nature of control measures. Demonstrated control techniques are discussed in terms of estimating efficiency and determining costs of implementation.

36. Delfiner, P. and R.O. Gilbert (1978). "Combining Two Types of Survey Data for Estimating the Geographical Distribution of Plutonium in Area 13." Selected Environmental Research Reports of the NAEG (NVO-192), Vol. 2, p. 361-404.

Estimates of average ${ }^{239,240} \mathrm{Pu}$ concentrations in surface $(0-5 \mathrm{~cm})$ soil lying within $30.5 \times 30.5 \mathrm{~m}$ cells are obtained for the inner fence region at the Area 13 safety-shot site on the NTS by using FIDLER ${ }^{241}$ Am measurements. Geometric mean estimates and factors for obtaining confidence intervals are listed. These estimates and approximate $95 \%$ confidence level are obtained using "kriging" in a two-stage procedure. 
37. Ebeling, L.L., R.B. Evans and E.J. Walsh (n.d.). Land Surface Cleanup of Plutonium at the Nevada Test Site. Reynolds Electrical and Engineering Co., Inc.

The purpose of this study was to test various soil-removing equipment in an environment similar to those contaminated at the NTS to determine which method best limited dust dispersal during clean-up procedures. The article also specifically describes the soil and topography of the NTS.

Remediation practices that have been tried for the safety test areas include both isolation and soil removal. The plutonium has been isolated by either spraying the soil surface with road oil or paving over it with asphalt. Plutonium has also been forced below the surface by leaching it with water or turning it over with a plow. Some trial areas have been decontaminated by scraping the top $15 \mathrm{~cm}$ of soil into windrows and hauling it elsewhere for burial. Removing the top $15 \mathrm{~cm}$ of soil over the entire contaminated area would result in over 1,600,000 square meters of waste that would require further processing or burial at an estimated cost of $\$ 300$ per square meter for a total cost exceeding $\$ 500,000,000$.

38. Eberhardt, L.L. and R.O. Gilbert (1974). "General Statistical Considerations in Environmental Plutonium Studies.” The Dynamics of Plutonium in the Desert Environment (NVO-142), p. 43-49.

This report is concerned with some general considerations having to do with the quantitative aspects of environmental plutonium studies. The high sampling variability encountered in environmental plutonium studies, along with high analytical costs, makes it very important that efficient sampling plans be used. Further attention to problems associated with compositing samples is recommended, as is the consistent use of random sampling as a basic technique.

39. Eckart, R. and T. Ijiaz (1991). Risk Assessment and Dose Analysis Workshop. Radiological Environmental Assessment Group, University of Cincinnati, Ohio.

This article deals with evaluating transuranic contaminations in general and the specific doses allowable to man regarding health to establish radiation standards. Discussed are environmental radiation standards, DOE, NRC, NCRP and EPA standards, recommended dose limits, pathway analysis methodology, source analysis, environmental transport, radiological exposure assessment (radionuclides in soil), evaluating risks, and concepts of ALARA and de minimis.

40. Essington, E.H. (1976). "Soil Radioactivity Distribution Studies for the NAEG." Selected Environmental Plutonium Research Reports of the NAEG (NVO-166), Vol. 1, p. 177-219.

The main theme of the NAEG is the determination and evaluation of radionuclide inventory and distribution in soils at selected study sites at the NTS. Several data sets are evaluated and are presented in this report. They include data relative to the vertical movement of plutonium and americium in desert soil profiles, and data relative to distribution of various isotopes of uranium in the blow-sand mounds at two study sites, one located at the NTS and the other at the Tonopah Test Range (TTR). 
41. Essington, E.H. and E.B. Fowler (1976). Distribution of Transuranic Nuclides in Soils: A Review. Transuranics in Natural Environments (NVO-178). Nevada Applied Ecology Group, Energy Research and Development Administration, Gatlinburg, Tennessee.

This paper reviews past documentation on the vertical distribution of transuranic and uranium nuclides in the terrestrial environment under natural or near-natural conditions. A very important aspect of plutonium migration into soils is the effect of time. Plutonium appears to migrate considerably after immediate introduction into the soil, with slower to minimal depth increases in later years. Observations were made in the hope of predicting future redistribution rates and indicating where additional evaluations are needed. Exemplified in the article, some ${ }^{239} \mathrm{Pu}$ was found to have migrated to 9 to $12 \mathrm{~cm}$ depths only 1.3 years after a safety-shot event. Two profiles taken 10 years later showed similar distributions.

42. Essington, E.H., E.B. Fowler, R.O. Gilbert and L.L. Eberhardt (1976). Concentrations in Nevada Test Site Soils Profiles. Transuranium Nuclides in the Environment, San Francisco, International Atomic Energy Agency, Vienna.

Approximately 70 soil samples were collected by the NAEG from five nuclear safety-shot sites on the NTS and TTR. The profile samples were analyzed for plutonium, americium, and uranium to estimate the depth of radionuclide penetration and level of contamination at specific sampling depths after an external period of time since deposition on the surface. About $50 \%$ of the profiles exhibited more than $95 \%$ of $\mathrm{Pu}$ in the top $5 \mathrm{~cm}$. In some cases, extrapolation beyond the $25-\mathrm{cm}$ depth indicated the probable presence of plutonium at greater depths. Plutonium distribution within the soil profile was influenced by the zone of transition between the A and B horizons and A and $C$ horizons, and appeared to accumulate in cemented lime/silica lenses. Other profile patterns are investigated and the implications of these observations are discussed with respect to redistribution of radioactivity by wind, water, burrowing animals, and clean-up operations.

43. Essington, E.H., R.O. Gilbert, E.B. Fowler and L.L. Eberhardt (1976). Plutonium, Americium, and Uranium in Concentration in NTS Soil Profiles. Transuranium Radionuclides in the Environment, San Francisco, International Atomic Energy Agency, Vienna.

Plutonium, americium, and uranium concentrations in the NTS soil profiles were investigated. Soil profile samples were collected by the NAEG from five nuclear safety-shot sites on the NTS and TTR. The profile samples were analyzed for plutonium, americium, and uranium to estimate the depth of radionuclide penetration and level of contamination at specific sampling depths after an extended period of time since deposition on the surface. Nearly 70 individual profiles were observed. About $50 \%$ of the profiles exhibited a smooth leaching pattern, with more than $95 \%$ of the $\mathrm{Pu}$ in the top $5 \mathrm{~cm}$. Other profile patterns are discussed relative to: 1) mechanical disturbance of the profile after the initial deposition; 2) accumulation of plutonium in specific zones within the soil profile; and 3) occurrence of large amounts of plutonium with respect to redistribution of radioactivity by wind, water, and burrowing animals, ingestion by burrowing and grazing animals, uptake by vegetation, and clean-up operations. 
44. Essington, E.H., R.O. Gilbert, D.L. Wireman, D.N. Brady and E.B. Fowler (1977). "Plutonium, Americium, and Uranium in Blow-Sand Mounds in Safety-Shot Sites at the NTS and Tonopah Test Range." Transuranics in Desert Ecosystems (NVO-181), p. 81-146.

Blow-sand mounds or miniature sand dunes and mounds created by burrowing activities of animals were investigated by the NAEG. Blow-sand mounds occupy as much as $30 \%$ of the area at some safety-shot sites. Understanding the relationship of $\mathrm{Pu}$ in these mounds has direct implications on the environmental inventory of $\mathrm{Pu}$.

The top portion of blow-sand mounds tend to have higher concentrations of $239,240 \mathrm{Pu}$ and ${ }^{241} \mathrm{Am}$ than the mound bottoms or surrounding desert pavement (top $5 \mathrm{~cm}$ ). Mound bottoms tend to have a greater total amount of ${ }^{239,240} \mathrm{Pu}$ and ${ }^{241} \mathrm{Am}$ associated with them than do mound tops. There seems to be no differential distribution of ${ }^{239,240} \mathrm{Pu}$ and ${ }^{241} \mathrm{Am}$, at least when mound top and mound bottom are compared. Burrowing animals appear to have mixed the mound contents or diluted the mound surface so that the concentration of ${ }^{239,240} \mathrm{Pu}$ and ${ }^{241} \mathrm{Am}$ is relatively uniform between the mound top and mound bottom. The mound bottom may include a remnant of the desert pavement; the mounds may have formed or moved to their present locations since the safety-shot events; or the mound bottom may be an effective receptor of $239,240 \mathrm{Pu}$ and ${ }^{241} \mathrm{Am}$ leached from the mound top.

45. Essington, E.H. (1978). "Soil Investigations for the NAEG: A Historical Review and Current Status." The Dynamics of Transuranics and Other Radionuclides in Natural Environments (NVO-272), Vol. 2, p. 197-259.

The soil compartment of the desert ecosystem contains almost all of the radionuclides produced by nuclear device testing at the NTS and TTR. Soils from seven safety-shot sites were investigated by the NAEG. The sites are GMX, Area 11, Area 13, Clean Slates 1, 2, and 3, and Double Track. Data included are the average ${ }^{239,240} \mathrm{Pu}$ to ${ }^{241} \mathrm{Am}$ ratios in soils of the various safety-shot sites, vertical distributions in the soil, and characteristics of the transuranics in blow-sand mounds.

46. Fowler, E.B., R.O. Gilbert and E.H. Essington (1974). "Sampling of Soils for Radioactivity: Philosophy, Experience and Results." Atmosphere-Surface Exchange of Particulate and Gaseous Pollutants, ERDA Symposium Series, Energy Research and Development Administration, p. 709-723.

The paper reviews aspects of one approach to the sampling of soils which has proved successful in a study of extensive areas where contamination with plutonium exists at a wide range of levels. Discussed is the development and field application of sampling techniques based on a designed random sampling scheme and on knowledge of contaminant distribution.

Typical results from participating laboratories are presented which indicate the degree of success experienced when the approach described is used to obtain data relative to inventory, horizontal and vertical distribution, and species of radionuclide.

47. Francis, C.W. (1973). "Plutonium Mobility in Soil and Uptake in Plants: A Review." J. Environ. Qual. Vol. 2, Issue 1:67-70.

Some recent long-term greenhouse studies indicate a substantially greater plant uptake of plutonium from a highly contaminated soil after five years of cropping as compared to the first year. Based on the general inability of heavy metals to be translocated within plants, it appears the most likely mode of plutonium entry into food chains leading to man would be that chelated with naturally occurring organic soil components. Chelation mechanisms have not been established. 
48. Gallegos, A.F. (1978). "Preliminary Model of Plutonium Transport by Wind at Trinity Site." Selected Environmental Research Reports of the NAEG, June 1978 (NVO-192), Vol. 2, p. $681-695$.

This report summarizes dust flux data from a ground zero location $1.6 \mathrm{~km}$ northeast of the Trinity crater along the fallout pathway, and examines the relationship between soil flux and plutonium flux, as well as other environmental parameters, using analysis of variance and regression analysis methods. The numerous charts and equations account for factors such as precipitation, soil moisture, wind speeds, air temperature, measurements of soil and plutonium creep, saltation, total dust fluxes, plutonium concentration, and size fractions in the soil.

49. Gilbert, R.O. and L.L. Eberhardt (1974). "Statistical Analysis of Pu in Soils at the NTS-Some Results." The Dynamics of Plutonium in Desert Environments (NVO-142), p. 51-89.

The primary objective of this paper was to design a field sampling plan that would result in a rather precise estimate of ${ }^{239,240} \mathrm{Pu}$ inventory in the upper $5 \mathrm{~cm}$ of soil of Are 5 and Area 13 on the NTS at a minimal cost. A secondary objective was to examine whether gamma scans for ${ }^{241} \mathrm{Am}$ and wet chemistry determinations of $239,240 \mathrm{Pu}$ were sufficiently well correlated so that $239,240 \mathrm{Pu}$ c.sncentrations could be predicted accurately using gamma scans. The third objective was to investigate whether the FIDLER could be used in a double sampling scheme for estimating plutonium concentrations on the soil surface.

The authors estimate the total amount of $239,240 \mathrm{Pu}$ in the upper $5 \mathrm{~cm}$ of soil inside the outer fence region of Area 13 from soil samples collected at randomly chosen locations according to a stratified random sampling plan. Correlation and regression analyses are computed, which indicate that laboratory gamma scans on soil samples for ${ }^{241}$ Am can predict quite well the concentrations of $239,240 \mathrm{Pu}$ present in soil. Average Pu/Am ratios are obtained for Areas 5 and 13 of the NTS and the TTR. The avera:e $\mathrm{Pu} / \mathrm{Am}$ ratio was not constant for each area and data suggest that the $\mathrm{Pu} / \mathrm{Am}$ ratio may not be constant over all levels of ${ }^{241} \mathrm{Am}$ for the lower count per minute regions of Areas 5 and 13. Correlations analyses indicate the FIDLER field instrument as used in current sampling programs is not accurate in predicting ${ }^{239,240} \mathrm{Pu}$ concentrations in surface soils, but may be useful in mapping the general surface distribution of ${ }^{239,240} \mathrm{Pu}$.

50. Gilbert, R.O., L.L. Eberhardt, E.B. Fowler and E.H. Essington (1974). "Statistical Design Aspects of Sampling Soil for Plutonium." Atmosphere-Surface Exchange of Particulate and Gaseous Pollutants. ERDA Symposium Series, Energy Research and Development Administration, p. 689-708.

Discussed are the various sampling techniques such as judgement, systematic, simple random, stratified random, and double sampling for assessing the amount of plutonium in soils at safety-shot sites on the NTS. The author explains the rationale for using stratified random sampling to estimate inventory and the kinds of analyses and design problems that have arisen.

Consideration is given to the accuracy of the FIDLER in measuring ${ }^{239} \mathrm{Pu}$ in surface soils as a prospect for reducing the cost of estimating plutonium inventory by using the approximate linear relationship between ${ }^{241} \mathrm{Am}$ and ${ }^{239} \mathrm{Pu}$. Discussion is also included on how soil sampling bias can arise at the time of aliquoting and whether analytical laboratories should report "less than" or "not detected" when radioisotope contamination above background is not detected. 
51. Gilbert, R.O., L.L. Eberhardt, E.B. Fowler, E.M. Romney, E.H. Essington and J.E. Kinnear (1975). "Statistical Analysis of ${ }^{239,240} \mathrm{Pu}$ and ${ }^{241} \mathrm{Am}$ Contamination of Soil and Vegetation on NAEG Study Sites." The Radioecology of Plutonium and Other Transuranics in Desert Environments (NVO-153), p. 339-448.

Estimates of ${ }^{239,240} \mathrm{Pu}$ inventory in surface soil (0-5 cm depth) are given for three safety-shot sites at the NTS and the TTR. The estimated ${ }^{239,240} \mathrm{Pu}$ inventories (in curies) for Area 13 and the GMX site in Area 5 are $44 \pm 8.8$ ( \pm standard error) and $2.5 \pm 0.30$, respectively. Those for the four Roller Coaster sites at TTR (Double 'Track, Clean Slates 1, 2, and 3) are 5.0 $\pm 1.4,5.2 \pm 1.6$, $29 \pm 6.2$, and $30 \pm 4.9$, respectively. The total ${ }^{239,240} \mathrm{Pu}$ inventory in Area 11 is estimated to be $39 \pm 4.4$ which is divided between B site $(6.2 \pm 1.0), C$ site $(8.9 \pm 1.9), D$ site $(18.5 \pm 3.5)$, a $C D$ overlap region $(0.81 \pm 0.34)$, and the low-level region surrounding these sites $(4.5 \pm 1.4)$. Profile samples indicate that most plutonium in soil is present in the top $5 \mathrm{~cm}$ of soil. This information and that obtained from a pilot study of profile samples in blow-sand mounds and desert pavement is discussed relative to the inventory of plutonium at greater depths.

Computer-drawn $239,240 \mathrm{Pu}$ concentration contours and three-dimensional "surfaces" in soil and vegetation are given for Area 13 and GMX as a method of estimating the geographical distribution of $239,240 \mathrm{Pu}$ at these sites.

52. Gilbert, R.O. and L.L. Eberhardt (1976). Some Design Aspects of Transuranic Field Studies. Transuranics in Natural Environments, Gatlinburg, Tennessee, Nevada Applied Ecology Group, Energy Research and Development Administration (NVO-178), p. 575-591.

In this paper, the authors discuss general guidelines that can be used to help design efficient transuranic field studies. The design of a transuranic field study depends on a number of factors including objectives, the quantity, the kind, and properties of radionuclides present (related to the source of contamination), the spatial distribution of the contamination over the study site, and a variety of practical considerations involving budget limitations. As a consequence, field sampling designs are necessarily site specific.

53. Gilbert, R.O. and L.L. Eberhardt (1976). "Some Statistical Design and Analysis Aspects for Nevada Applied Ecology Group Studies." Studies of Environmental Plutonium and Other Transuranics in Desert Ecosystems (NVO-159), p. 101-115.

Some of the design and analysis aspects of the NAEG studies at safety-shot sites are reviewed in conjunction with discussions of possible new approaches. The authors have been actively involved in the statistical design and analysis aspects of these studies and review these methods.

The use of double sampling to estimate inventories is suggested as a means of obtaining data for estimating the geographical distribution of plutonium using computer contouring programs. The lack of estimates of error for plutonium contours is noted and a regression approach is discussed for obtaining such estimates. The kinds of new data that are now available for analysis from $A$ site of Area 11 and the four TTR sites are outlined, and the need for a closer look at methods for analyzing ratio-type data is pointed out. Some general planning aspects of new studies at nuclear sites and experimental clean-up lots are discussed, as is the planning of interlaboratory comparisons. 
54. Gilbert, R.O. and E.H. Essin gton (1977). "Estimating Total ${ }^{239,240} \mathrm{Pu}$ in Blow-Sand Mounds of Two Safety-Shot Sites." Transuranics in Desert Ecosystems (NVO-181), p. 367-408.

This paper discusses methods for estimating plutonium inventory in blow-sand mounds. Estimates for the total $239,240 \mathrm{Pu}$ mound inventory are broken down into estimates for mound tops and bottoms of five different mound types at 'wo safety-shot sites: Area 13 (Project 57) on the Nellis Air Force Range (NAFR) and Clean Slate 3 on the TTR. The total amount in blow-sand mounds at these two sites is estimated to be $5.8 \pm 1.3$ and $10.6 \pm 2.5$ curies, respectively. The total $239,240 \mathrm{Pu}$ in mounds plus desert pavement areas, both to a depth of $5 \mathrm{~cm}$ below desert pavement level, is estimated to be $39 \pm 5.7$ curies at the Project 57 site and $36 \pm 4.8$ curies at Clean Slate 3. Discussed is the distribution and concentration of plutonium in the blow-sand mounds and the relationship of plutonium in the blow-sand mound to that of the surrounding desert pavement.

55. Gilbert, R.O. and E.H. Essington (1977). "Formulas for Estimating the Total Inventory of ${ }^{239,240} \mathrm{Pu}$ in Blow-Sand Mounds." Transuranics in Desert Ecosystems (NVO-181), p. 409-422.

This paper is an appendix of formulas for estimating the total inventory of $239,240 \mathrm{Pu}$ in blow-sand mounds. The paper is divided into two sections. Section 1 deals with methods used for grass, shrub, complex, and animal mounds, while Section 2 discusses methodology used for diffuse mounds.

56. Gilbert, R.O. (1978). "Revised Total Amounts of Plutonium 239,240 in Surface Soil at Safety-Shot Sites." Transuranics in Desert Ecosystems (NVO-181), p. 423-429.

Corrected estimates of ${ }^{239,240} \mathrm{Pu}$ in surface soil $(0-5 \mathrm{~cm})$ are given for 10 safety-shot sites on the NTS, TTR, and NAFR. Revised estimates for Area 11 are reported. These adjustments result from using more accurate estimates for the sizes of americium activity strata than were originally reported by Gilbert et al. (1975). Revised estimates of $239,240 \mathrm{Pu}$ inventory associated with vegetation are also given.

57. Gilbert, R.O. (1978). "On the Estimation of Spatial Pattern for Environmental Contaminants." Selected Environmental Research Reports of the NAEG (NVO-192), Vol. 2, p. 319-360.

This paper examines the performance of an iterative procedure used for the estimation of grid values to determine the geographical distribution of environmental contaminants. A two-phase least squares procedure is applied three times: first to observed data, then to the residuals from the first fit, and finally to the residuals from the second fit. The three estimated grids are added together for the final grid estimates. Results are displayed as contour maps, three-dimensional surfaces, and plots of residuals.

This method was employed by the NAEG using data from a safety-shot site on the NTS. For these data, the iterative procedure reduces the standard deviation and average absolute size of residuals and increases the percent of the total variation explained by fits in both untransformed and antilog data. The iterative procedure applied to the log-transformed data appears to result in more reasonable estimates of concentration surface at locations where samples are not collected than did fits obtained on transformed data. Fits in either scale, especially in the untransformed scale, gave questionable estimates in regions of sparse data where plutonium concentrations change rapidly within short distances. 
58. Gilbert, R.O., J.H. Shinn, E.H. Essington, T. Tamura, E.M. Romney, K.S. Moor and T.P. O'Farrel (1988). “Radionuclide Transport from Soil to Air, Native Vegetation, Kangaroo Rats, and Grazing Cattle on the Nevada Test Site." Health Physics 55(6):869-887.

Between 1970 and 1986, thic NAEG and DOE conducted environmental radionuclide studies at safety-shot sites in Area 13 and at Clean Slate 2 regarding soil particle-size distribution and physical characteristics of ${ }^{239,240} \mathrm{Pu}$-bearing radioactive particles, ${ }^{239,240} \mathrm{Pu}$ resuspension rates, and transuranic radionuclide transfers from soils to native vegetation, kangaroo rats, and grazing cattle.

Compared to the nuclear sites, Area 13 has orders-of-magnitude higher resuspension factors; a higher percentage of radioactivity in smaller soil particle-size fractions; a larger percentage of resuspendable and respirable soil and GM carcass-over-soil, GI-over-soil, and pelt-over-soil ${ }^{239} \mathrm{Pu}$ ratios many times larger than those at Clean Slate 2. The data indicate that the transuranic radionuclide contamination in the soil at the non-nuclear Area 13 site may be transferred more readily to plants and animals than the transuranic radionuclide soil contamination at Clean Slate 2.

59. Gillette, D.A. (1974). "On the Production of Soil Wind Erosion Aerosols Having the Potential for Long Range Transport." J. Rech. Atmos. 8(3/4):735-744.

The production of soil-wind erosion aerosols expressed as vertical flux of particulate matter was measured for several wind speeds on two soils of distinct textural types with similar erosion conditions. The vertical fluxes of aerosols could be described roughly by the relationship: vertical aerosol flux $\alpha$ (wind speed/threshold erosion wind speed) $\gamma$, where wind speed is greater than threshold wind speed and where $\gamma$ is $>3$ and is larger for the soil having more silt content per unit mass. The probable explanation for the above is that increased disintegration of soil aggregates with increased wind speed causes larger proportions of particles $\mathrm{r}<10 \mu \mathrm{m}$ in the injected particulate.

60. Gillette, D.A. (1974). Production of Fine Dust by Wind Erosion of Soil: Effect of Wind and Soil Texture. Atmosphere-Surface Exchange of Particulate and Gaseous Pollutants, CONF-740921, Richland, Washington, p. 591-608.

Airborne particulate material was sampled at several levels from 0 to $1.3 \mathrm{~cm}$ to $6.8 \mathrm{~m}$ when wind erosion of the soil was taking place. The sampling locations were large, flat, unvegetated fields of uniform soil texture. Size distributions of airborne particles may be described as bimodal lognormal mass distributions. The size distributions of airborne particles within $1 \mathrm{~cm}$ of the ground were highly similar to the dry aggregate size distribution of the soils at the sampling locations. The size distributions change with distance from the ground due to gravitational sedimentation of the largest particles. Horizontal fluxes of sand $(q)$ were measured and vertical fluxes of aerosol $1 \mu \mathrm{m}<\mathrm{r}$ $<10 \mu \mathrm{m}\left(\mathrm{F}_{\mathrm{a}}\right)$ were computed from the aerosol and wind observations.

61. Gillette, D.A., I.H. Blifford and D.W. Fryrear (1974). "The Influence of Wind Velocity on the Size Distribution of Aerosols Generated by the Wind Erosion of Soils." Journal of Geophysical Research 79(27):4068-4075.

The authors suggest that the sandblasting of the soil surface is the dominant mechanism of fine soil wind erosion once saltation has started. The relationship of the relative size distribution of soil wind erosion aerosols to wind velocity was examined. The ratio of the sedimentation velocity to the friction velocity at which aerosol particles were appreciably affected by settling was larger than 0.12 and smaller than 0.68 . The size distribution shape of aerosols $2 \mu \mathrm{m}<\mathrm{r}<10 \mu \mathrm{m}$ was rather constant with wind speed. Agitating the soil added to the total number of dry aggregate soil particles, but it did not change the relative size distribution of particles $<10 \mu \mathrm{m}$. 
62. Gillette, D.A., J. Adams, D. Muhs and R. Kihl (1982). "Threshold Friction Velocities and Rupture Moduli for Crusted Desert Soils for the Input of Soil Particulates into the Air." Journal of Geophysical Research 87(C11):9003-9015.

Desert soils having clay crusts were tested for threshold friction velocity with an open-bottomed wind tunnel. Force was applied to the various crusts to determine the soil susceptibility to wind erosion. A weak crust will protect the soil from typical wind patterns, while a disturbed soil will be highly erodible if the crust breaks easily. Soils that did erode in undisturbed conditions had a thin and weak surface crust, and the solid surface had loose sand or pellet-sized material present. If lose particles are on the surface, the movement of these particles during high winds tend to break up weak soil crusts. For the case of loose material on the surface, threshold friction velocity was related to the mode of the mass size distribution of the loose material. The harder and thicker the crust, the larger the mode of the aggregate size distribution. Disturbed soils with undisturbed modulus of rupture $>2$ bars will have threshold friction velocity roughly proportional to modulus of rupture times (thickness of crust) 2 . Aerodynamic roughness heights were roughly the same or smaller following disturbance by a truck tire due to a smoothing of the surface by crushing and mixing of aggregated soils and surface deposits.

63. Gillette, D.A. and K.J. Hanson (1989). "Spatial and Temporal Variability of Dust Production Caused by Wind Erosion in the United States." J. of Geophys. Res. 94(D2):2197-2206.

Dust production is enhanced by both the lowering of threshold velocities and by increasing wind speed. Wind erosion maximizes the rate of dust emissions in the spring when wind speeds are at maximum velocities, and protection of the soil by vegetation is minimal. Minimal rates of erosion occur in the summer when low wind speeds are typical and high threshold velocities are created by increased vegetation cover.

Wind erosion is the mathematical expectation of the third power of wind speed. Because dust production proceeds roughly as the fourth power of wind speed and is integrated from a threshold wind speed, the spatial patterns of wind energy might be regarded as very similar to those for dust production having 0 threshold velocity.

64. Hakonson, T.E., R.L. Watters and W.C. Hanson (1981). "The Transport of Plutonium in Terrestrial Ecosystems." Health Physics 40:63-69.

When released to terrestrial ecosystems, plutonium is almost quantitatively transferred to and retained by soils. Thus, processes which transport soil within ecosystems predominate in the transport of environmental plutonium. These transport processes are driven by wind, water, biotic, chemical, and mechanical activity. Also discussed is plutonium associated with blow-sand accumulations and other vegetation relationships. The main factor limiting our ability to predict plutonium transport in ecosystems is the limited knowledge of ecosystem structures and functions. 
65. Hanson, W.C. (1975). "Ecologiggl Considerations of the Behavior of Plutonium in the Environment." Health Physics 28:529 537.

This paper summarizes and discusses the available information on the subject of plutonium in the environment from an ecological standpoint. The radiological considerations of plutonium released into the environment are logically based upon an understanding of ecostructure and function. Studies of plutonium in the atmosphere, lithosphere, terrestrial ecosystem of the biosphere, and in the hydrosphere are reviewed. Also discussed is the complexity of predicting the resuspension of plutonium due to the staggering number of environmental variables that involve several phenomena that are within themselves highly variable in time and place.

\section{Hartmann, G., C. Thom and K. Bachman (1989). "Sources of Pu in Near Surface Air." Health Physics 56:55-69.}

The different measurements of the plutonium concentrations in the air as a function of time and size distribution leads the authors to assume that most of the $\mathrm{Pu}$ in near-surface air is attached to resuspended matter, whereas ine injection from the stratosphere has decreased to rather low values. This is confirmed by the vertical distribution in near-surface air, where highest Pu concentrations are found in the layer between zero and five meters above ground.

The annual decrease of plutonium in near-surface air is correlated with the decrease of $\mathrm{Pu}$ in the uppermost soil layer. The decrease of $\mathrm{Pu}$ in the air is no longer determined by the decrease of stratospheric fallout, but by the decrease of resuspension due to the weathering-in of plutonium into the soil.

Particle-size distribution demonstrates that plutonium is enriched in aerosols of about 3 micrometers. There are two possible intespretations. First, aerosols at about 3 micrometers have physical or chemical properties which allow a better attachment of plutonium than other size particles. Second, the specific weight of $\mathrm{Pu}$-containing particles is much higher than the specific weight of other resuspended aerosols.

67. Healy, J.W. (1971). Some Thought on Plutonium in Soils. Proceedings of Environmental Plutonium Symposium, Los Alamos Scientific Laboratory, University of California, Los Alamos, New Mexico. National Technical Information Service, U.S. Department of Commerce, Springfield, Virginia.

Inhalation of resuspended plutonium from contaminated soils offers a significant health risk and encourages a comprehensive understanding of resuspension phenomena. Typically, a resuspension factor is employed to represent resuspended contaminants. This factor is the ratio of the air concentration at a given location to the quantity per unit area on the ground at that location. This method does not account for the size of the area or the possible existence of highly contaminated areas upwind.

Healy suggests an approach that considers the mechanisins of resuspension separately from those of deposition and dispersion in the atmosphere. Each area can be considered as a source of airborne material and the concentration at any point downwind can be calculated by use of the correlations derived from atmospheric dispersion and deposition studies and by integration over the area of deposition. The magnitude of the pickup rate can be studied by measuring the concentration downwind from a source on the ground under various conditions of natural or artificial disturbance. By acquiring information on the source, the meteorological conditions and the airbome concentrations, an estimate may be made for the resuspension concentrations that may differ for different areas in which the size, distribution of the material and particle size may differ. 
68. Healy, J.W. (1976). A Review of Resuspension Models. Transuranics in Natural Environments (NVO-178), Gatlinburg. Tennessee, Nevada Applied Ecology Group, Energy Research and Development Administration, p. 211-222.

Resuspension is classified, according to the prominent path of exposure and the type of consideration involved in estimating concentrations, as general resuspension, local resuspension, and transfer resuspension. General resuspension can be driven by winds or mechanical disturbances, while local resuspension and transfer resuspension are primarily caused by mechanical disturbances. Modeling techniques consist of the resuspension factor, the resuspension rate, and mass-loading. For general resuspension, the resuspension rate is preferred, while the resuspension factor or mass loading approach can be used for local resuspension.

69. Henderson, R.W. and R.F. Smale (1990). "External Exposure Estimates for Individuals Living Near the Nevada Test Site." Health Physics 59(5):715-721.

Individuals living near the NTS were exposed to radiation from fission products and activation products resulting from the atmospheric testing of nuclear devices. These exposures and the resultant doses were functions of the amount of material deposited, the time arrival of debris, and the amount of shielding afforded by structures. Results are presented for nine generic lifestyles These are representative of people living in the area. The calculated results were extrapolated to the present. Calculations yielded estimates for various health issues.

70. Horst, T.W. (1.982). "The Estimation of Airborne and Surface Contamination Resulting from the Deposition-Resuspension Process." Health Physics 43(2):269-272.

The author discusses the faults of the Resuspension Factor Model and Resuspension Rate Model in estimating the airborne and surface contamination resulting from the deposition-resuspension process. The weakness of the Resuspension Factor Model is that it is based on limited data, does not accurately describe the spatial distribution of resuspended contamination and it is dependent on upwind rather than local surface contamination. The Resuspension Rate Model calculates the resuspended contamination by accounting for atmospheric transport and diffusion between the receptor and the upwind distribution of surface contamination. This model is weak due to a lack of data on resuspension and weathering rates. The author recommends that future models account for the resuspension fluxes and surface deposition via terrestrial pathways.

71. Horton, J.H. and J C. Corey (1980). "Distribution of Surface Deposited Plutonium in Soil After Cultivation." Health Physics 38:697-699.

It is hypothesized that the hazards of radionuclides near or on the soil surface can be greatly reduced by disking to mix the radionuclides with a large volume of soil. Such dilution would be useful for plutonium since its greatest hazard to man is by inhalation of airborne particles. Tillage, including 8 to 10 diskings, did produce slight increases in the Pu concentrations in the 5 to $15 \mathrm{~cm}$ depth of soil in both fields, indicating some mixing of the 0 to $5 \mathrm{~cm}$ and 5 to $15 \mathrm{~cm}$ depths, but the amount of mixing was surprisingly small. The only other significant change was a reduction of the Pu concentration in the 15 to $30 \mathrm{~cm}$ depth of soil with no apparent explanation for this phenomenon. 
72. Iranzo, E., S. Salvador and C.E. Iranzo (1987). "Air Concentrations of 239 and 240 Pu and Potential Radiation Doses to Persons Living Near Pu-Contaminated Areas in Palomares, Spain." Health Physics 52(4):453-461.

This article discusses the $\mathrm{i}$ arious air-monitoring procedures used to assess the potential radiation dose of ${ }^{239} \mathrm{Pu}$ and ${ }^{240} \mathrm{Pu}$ created when two military weapons experienced non-nuclear expission and release of fissile fuel. Cleanup consisted of removing contaminated soils to depths of 10 to $30 \mathrm{~cm}$ and replacing with noncontaminated soils. This procedure was believed to remove any $\mathrm{Pu}$-isotope inhalacion risks from resuspension to people living in the surrounding areas. Air monitoring irdicated that radionuclides in the air were below acceptable dose limits.

73. Johnson, C.J., R.R. Tidball and R.C. Severson (1976). "Plutonium Hazard in Respirable Dust on the Surface of Soil." Science 193:488-490.

Standards designed to measure the risk of plutonium in soils should focus on the respirablesized soil fractions. The greatest long-term hazard for the resuspension of plutonium from contaminated soils occurs where both the concentration per gram and the percentage of material $\leq 5$ $\mu \mathrm{m}$ are high. Contaminated soils should be measured against a background of Pu released from atmospheric weapons testing. It is proposed that this method of evaluation defines more precisely the health hazard from the respirable fraction of plutonium-contaminated soils.

74. Jordan, H.S. (1971). Distribution of Plutonium from Accidents and Field Experiments. Proceedings of Environmental Plutonium Symposium, Los Alamos Scientific Laboratory, University of California, Los Alamos, New Mexico. National Technical Information Service, U.S. Department of Commerce, Springfield, Virginia.

Since the Limited Test Ban Treaty, the fallout from weapons testing has diminished but concern should be emphasized on nuclear products as components of weapons, fuel, and waste products. The author outlines studies of plutonium in the environment from accidents involving nuclear weapons and from safety shots. Among areas examined are Area 11 at the NTS and the Roller Coaster Site on the TTR. The author concludes that further study of these similar experiments are necessary to ensure public safety and successfully resolve large-scale plutonium contamination accidents.

75. Joussame, S. (1990). "3-D Simulations of the Atmospheric Cycle of Desert Dust Particles Using A General Circulation Model.” J. of Geophys. Res. 95(D2):1909-1941.

This work discusses a modeling of the atmospheric cycle of desert dust particles within an atmospheric general circulation model. Factors in the model climatology include different sea level pressures, wind fields, and precipitation fields. One of the important results of these simulations is a strong seasonal dependence of the dust plumes, with twice more dust in the summer than in the winter. This seasonal contrast essentially results from changes in the atmospheric circulation, particularly in the vertical distribution of the dust amounts.

76. Kerhcer, J.R. and L.R. Anspaugh (1991). "Analysis of the NAEG Model of Transuranic Radionuclide Transport and Dose." Environ. Radioact. 13:191-216.

This article analyzes the NAEG model of transuranic radionuclide transport and dose that employs sensitivity and uncertainty analysis.

The sensitivity analysis indicates that the inhalation pathway is the critical pathway for the organs receiving the highest dose. The soil concentration and the factors controlling air concentration are the most influential factors. 
Uncertainty analysis can reflect measurement error or an intrinsic variability in the parameter. This exercise will tell the range of output to be expected from independent parameters. The uncertainty analysis indicates that choosing a square or uniform distribution for the input parameters results in a lognormal distribution of dose.

77. Kirby, F.R., L.R. Anspaugh, P.L. Phelps, G.W. Huckabay, F.R. Markwell and M.G. Barnes (1978). "A Comparison of In Situ Gamma Soil Analysis and Soil Sampling Data Mapping ${ }^{241} \mathrm{Am}$ and ${ }^{239} \mathrm{Pu}$ Soil Concentrations at the Nevada Test Site." Transuranics in Desert Ecosystems (NVO-181), p. 147-158.

Soil sampling and in situ ${ }^{241}$ Am-gamma counting with an array of four high-purity, planar, Ge detectors are compared as means of determining soil concentration contours of plutonium. Results of this survey, which covered an area of approximately $300,000 \mathrm{~m}^{2}$, indicate that with one-third the number of sampling locations, the in situ gamma survey provided soil concentration contours with confidence intervals that were about one-third as wide as those obtained with soil sampling. The overall errors associated with the in situ method are lower than those associated with soil sampling and obtaining the in situ data is less costly.

78. Kocher, D.C. (1980). "Potential Importance of Resuspension During Chronic Releases of Radionuclides to the Atmosphere." Health Physics 39:687-690.

Models which have been proposed to describe the resuspension factor are used to predict air concentration and exposures from resuspension during a long-term chronic release to the atmosphere. The concentration from resuspension predicted by some of the models is larger than the contribution from direct atmospheric transport. This result casts doubt on the validity of the resuspension models and indicates the need for a re-examination of the values of the model parameters.

79. Lane, L.J., T.E. Hakonson and G.R. Foster (1983). Watershed Erosion and Sediment Yield Affecting Contaminant Transport. Environmental Research on Actinide Elements, Hilton Head, South Carolina, U.S. Department of Energy, p. 193-224.

Reiationships between sediment-associated contaminants and erosion and sedimentation processes are described, and some gaps in knowledge (with respect to erosion and sediment modeling) for improved understanding and contaminant transport and redistribution are identified. Two upland erosion models are described in detail and criteria for application of more complex watershed models are identified and explained. New applications in modeling erosion and sediment yield are outlined and a computer simulation model is introduced.

80. Langham, W. (1959). The Problems of Large-Area Pu Contamination. U.S. Department of Health, Education, and Welfare.

Langham was one of the first field monitors for large-area plutonium contamination during the explosion of the first plutonium fission weapon in 1945 in New Mexico. Langham discusses the physiology and toxicology of plutonium and some examples of large-area plutonium contamination. Langham was one of the first scientists to attempt to evaluate the risk of large-scale plutonium contamination. He suggests that a method for the decontamination of large-scale Pu be considered before an incident occurs, but that the variables of such a contamination are so many and variable that it would be naive to establish any one single set of standards that would apply specifically to any and all situations. 
81. Layton, D.W., L.R. Anspaugh, K.T. Bogen and T. Straume (1992). Risk Assessment of Soil-Based Exposures to Plutonium at Safety-Shot Sites Located at the Nevada Test Site and Adjoining Areas. Lawrence Livermore National Laboratory.

To discuss the magnitude of the potential health risks for the NTS, three basic exposure scenarios that could bring individuals in contact with $239,240 \mathrm{Pu}$ were investigated: 1 ) a resident living in a subdivision located at the test site; 2 ) a resident farmer, and 3) a worker at a commercial facility. The screening analyses indicated that internal doses to organs are dominated by the inhalation pathway, and thus the risk assessment focused on those factors that affect inhalation exposures and associated doses. Cancer risks were calculated as a function of lifetime cumulative doses to the key target organs and risk factors for those organs.

The predicted cancer risks for the resident farmer were more than a factor of three higher than the suburban resident at the median risk level and about a factor of 10 greater than the reference worker at a commercial facility.

82. Leavitt, V.D. (1978). "Soil Surveys and Profile Descriptions of Plutonium Contaminated Areas on the Test Range Complex in Nevada; 1970-1977." Selected Environmental Reports of the NAEG (NVO-192), Vol. 1, p. 253-264.

This report discusses soils in five areas located on the NTS. The areas are Clean Slate 1, 2, and 3, Double Track, GMX, Area 11, and Area 13. Most of the surface soils in these areas have a gravelly texture and are typically classified as gravelly sandy loam. The majority of the surveyed land is either floodplain or alluvial fan, with deep soils having well-developed profiles and platy structure. All of the soils are alkaline.

Area 11 soils are described as gravelly loam with a platy surface structure containing a pH range of 8.0 to 8.8 with moderate water permeability, offering no agricultural potential. Soil movement occurs by slight wind erosion over level to $2 \%$ slopes with the dominant vegetation being fourwing saltbrush.

83. Lee, S.Y. and T. Tamura (1981). "Distribution and Characterization of Radionuclides in Soils from the Nevada Test Site.” J. Environ. Qual. 10:234-239.

Physicochemical properties of $\mathrm{Pu}$-bearing radioactive particles and their association with host soils from the NTS were studied to provide data for potential clean-up operations. The dominant radioactive particles were very fragile by compression tests and extremely porous with a particle density $<2.26 \mathrm{~g} / \mathrm{cm}$. Physical properties of the particles suggested that they could be broken into respirable sizes by saltation during wind erosion, and that their physical properties could be useful for mechanically separating them from the nonradioactive soil particles. Experimental results revealed that more than $90 \%$ of the total radioactivity was recovered in about $25 \%$ of the total sample weight through density separation techniques, and in about $18 \%$ of the total weight by a grinding-sieving process. Radioactive particles might be removed from the contaminated soil by: 1) a controlled vacuum collector; 2) density separation; 3) grinding-sieving separation; or 4) by a combination of these techniques. 
84. Ligotke, M.W. (1993). Soil Erosion Rates Caused by Wind and Saltating Sand Stresses in a Wind Tunnel. Pacific Northwest Laboratory, Batelle, PNL-8478/UC-702.

Wind erosion tests were performed in a wind tunnel to provide information useful to the design and evaluation of the surface layer composition of an arid-region waste site barrier that consists of a deep fine-soil reservoir. Test results include characterization of wind and saltating sand stresses and the impact of deflation rates of wind speed, soil moisture, admixture particle size, surface layer sand content, and sand saltation rate and intensity.

Test data provided evidence supporting the use of pea gravel admixtures to protect the fine-soil reservoir from eolian stresses. Compared with rates caused by applied wind stresses and measured from unprotected soil surfaces, pea gravel armors reduced deflation rates by $93 \%$ at $15 \mathrm{~m} / \mathrm{s}(34 \mathrm{mph})$ and by at least $96.5 \%$ to more than $99.4 \%$ at wind speeds of 20,25 , and $30 \mathrm{~m} / \mathrm{s}(45$, 56 , and $67 \mathrm{mph}$ ). Surface protection afforded by pea gravel also extended to applied sand saltation erosive stresses. Exposed gravel absorbed the impact energy of saltating sand grains and resulted in deflation rates at least $45 \pm 6$ times less than those from unprotected soil surfaces.

85. Maza, B.G. (1991). Index of the Nevada Applied Ecology Group and Associated Publications Available in the Coordination and Information Center. Reynolds Electrical and Engineering Co., Inc.

This publication is an index of the NAEG and associated publications available in the Coordination and Information Center (CIC). The CIC is an archive and a research facility operated by REECo for the DOE in Las Vegas, Nevada. The purpose of the CIC is to provide information on off-site radioactive fallout from nuclear weapon tests and other selected subjects. These citations represent a significant portion of the principal research and findings of the NAEG.

86. McArthur, R.D. and S.W. Mead (1989). Nevada Test Site Radionuclide Inventory and Distribution Program: Report \#5. Areas 5, 11, 12, 15, 17, 18, 19, 25, 26, and 30. Desert Research Institute, Water Resources Center, University of Nevada System, Publication No. 45067.

The purpose of this article is to assess areas of high-risk transuranic contamination on the NTS. Assessments were made using aerial photos and in situ testing. Most of the data for estimating radionuclide inventories and distributions came from measurements of gamma radiation acquired in situ by a gamma spectrometer fitted with a high-purity germanium detector. The measurements were taken on a grid of points covering each area of interest.

87. Mewhinney, J.A., A.F. Edison and V.A. Wong (1987). "Effect of Wet and Dry Cycles on Dissolution of Relatively Insoluble Particles Containing Pu." Health Physics 53(4):377-384.

This article discusses the characteristics of plutonium under wet-dry cycle phenomenon, most notably the flash flood and arid desert conditions.

Dissolution of gross emitter radioactivity from particles composed of mixed uranium and plutonium oxides or of plutonium dioxide continually immersed in solvent typically display at least a two-phase dissolution pattern. In this study, respirable particles of $(\mathrm{U}, \mathrm{Pu}) \mathrm{O}^{2}$ and $\mathrm{PuO}^{2}$ were subjected to dissolution using an alternate wetting and drying cycle. Four solvents were used in dissolution: distilled water, distilled water with DTPA, simulated acid rain, and simulated acid rain with DTPA. The mean percentage of the initial gross radioactivity dissolved in each solvent ranked in the order: distilled water $<$ distilled water + DTPA $<$ simulated acid rain $<$ simulated acid rain + DTPA $<0.1 \mathrm{M} \mathrm{HCI}$. 
88. Mork, H.M. (1970). Redistribution of Plutonium in the Environs of the Nevada Test Site. Laboratory of Nuclear Medicine and Radiation Biology, University of California, Los Angeles.

Surveys were made 10 months and 2 years after safety shots to assess the residual plutonium levels in the environment. Redistribution of plutonium in the air was still occurring two years after detonation and was found to be in greater concentrations near the ground level. These airbome concentrations were significant and some were $100 \%$ the maximum permissible concentration for continuous exposure in air. The concentrations in one area were higher after two years than initially after detonation. The residual plutonium content in the soil was highest near the ground zeros. At one site, the presence of plutonium in the soil decreased from 11.7 to 3.48 micrograms per square meters of soil. Results of Pu concentration in soils at other sites were questionable due to the presence of beta-emitting plutonium in significant amounts, perhaps from weapons testing prior to safety-shot activities.

Recognizing that aerosol particle samples are typically distributed lognormally with respect to particle size, initial rapid dissolution may be due to dissolution of the very smallest particles at a more rapid rate. Further, highly irregularly shaped particles have increased the occurrence of high free-energy surface sites (points and edges) where the solid dissolves more rapidly than from smooth surfaces.

89. Musick, H.B. and D.A. Gillette (1990). "Field Evaluation of Relationships Between a Vegetation Structural Parameter and Sheltering Against Erosion." Land Degradation and Rehabilitation 2:87-94.

This article discusses a method to predict the degree of sheltering afforded by vegetation. Vegetation shelters erodible soil surfaces from wind erosion by acting as aerodynamic roughness elements that absorb a portion of the total shear stress imparted by the wind. Vegetation canopy measurements may be used to estimate lateral cover (total frontal silhouette area per unit of ground area) and to predict shear stress partitioning. This method was compared to wind tunnel experiments done in vegetated soils versus the same soil unvegetated, and was found to be a fairly accurate assessment of shear stress partitioning.

90. NEA Experts Report (1981). The Environmental and Biological Behavior of Plutonium and Some Other Transuranium Elements. Nuclear Energy Agency Organization for Economic Cooperation and Development.

This report reviews the basic information about plutonium and other transuranics and their environmental and biological significance. Discussed are the chemical properties and formation of transuranium elements and the health risks incurred by the introduction of these elements to man. Transport by atmospheric, terrestrial and aquatic pathways are investigated. Discussed are various sources for transuranic exposure and numerous special examples are cited (including the Nevada Test Site). A complete glossary concludes the report. 
91. Nicholson, K.W. (1988). "A Review of Particle Resuspension." Atmospheric Environment 22(12):2639-2651.

Resuspension by wind is investigated as well as by other processes such as raindrop impact, and mechanical disturbances caused by pedestrians, vehicles and agricultural practices. Erosional characteristics of various-sized particles are discussed in respect to threshold velocities and roughness factors. The applications and inadequacies of the Resuspension Rate and Resuspension Ratio formulas are reviewed. Creating a formula to denote resuspension will require inclusion of numerous factors including adhesion and removal of particles at the surface, the time dependence of resuspension, wind speed, and particle size.

92. Nickling, W.G. and J.A. Gillies (1989). "Emission of Fine-Grained Particulates from Desert Soils." Paleoclimatology and Paleometeorology: Modern and Past Patterns of Global Atmospheric Transport, p. 133-165.

The lack of consistent relationships between the mean size of aerosols in the 1 to $10 \mu \mathrm{m}$ size range with shear velocity and textural characteristics of the parent soil has been noted by various authors.

Results from the wind tunnel tests showed no clear relationship between mean grain size and threshold shear velocity $\left(U^{*}\right)$ for 13 Arizona sites. This most likely results from the similarity of modal diameters for the sampled sites and the complicating effects of other surface parameters such as vegetation and surface crusting, which are not evaluated in a simple bivariate relationship. Concentration of suspended sediment over eroding surfaces decreases as a power function of height.

93. Nishita, H. (1979). A Review of Plutonium in Soils and Other Geologic Materials. Prepared for U.S. Nuclear Regulatory Commission by Laboratory of Nuclear Medicine and Radiation Biology, University of California, Los Angeles.

Available information on the physical and chemical reactions of $\mathrm{Pu}$ in soils and other geologic materials is reviewed. The review is divided into two general categories: studies of chemical reactions of $\mathrm{Pu}$ in aqueous solutions and studies of $\mathrm{Pu}$ reactions in the more complex systems of soils and other geologic materials. The latter category is further divided into studies of $\mathrm{Pu}$ in materials that were freshly contaminated in the laboratory and of $\mathrm{Pu}$ in materials that had been contaminated in natural environments and had resided there for varying number of years. Several reported examples of the actual movement of $\mathrm{Pu}$ in terrestrial environments are given.

\section{O'Farrell, T.P. and L.A. Emery (1976). Ecology of the Nevada Test Site: A Narrative} Summary and Annotated Bibliography.

This document contains a summary of the ecology of the NTS in the form of an annotated bibliography and species lists. Discussed are the location of the test site, its geology, hydrology, climate, soils, flora, fauna, and its endangered and threatened species.

95. Phelps, P.L. and L.R. Anspaugh (1974). “Resuspension Element Status Report." The Dynamics of Plutonium in the Desert Environment (NVO-142), p. 221-233.

Measurements using cascade impactor studies indicate that there is no difference in the distribution of activity with particle size for three species: ${ }^{238} \mathrm{Pu},{ }^{239,240} \mathrm{Pu}$, and ${ }^{241} \mathrm{Am}$. The total mass, however, was found to be distributed distinctly differently with a smaller median aerodynamic diameter and a larger geometric mean. 
Experimental results have also shown that there is no obvious correlation of specific $\mathrm{Pu}$ activity with particle size. An average specific activity of $890 \mathrm{dpm} / \mathrm{g}$, or about one-third of that found in the soil in close proximity to the cascade impactors, showed that the ratio of ${ }^{239,240} \mathrm{Pu}$ to ${ }^{241} \mathrm{Am}$ activity is the same as reported for soil in the vicinity of the cascade impactors. Preliminary results from the ultrahigh-volume air sampler runs indicate a gross correlation between many of the wind speed-related parameters and the concentration of resuspended plutonium

96. Phelps, P.L. and L.R. Anspaugh (1975). Resuspension Element Status Report. Energy Research and Development Administration, Nevada Operations Office, Las Vegas, Nevada.

Field studies have been conducted at the GMX area of the NTS with the goal of developing a parameterization of the variables related to resuspension of plutonium. The historical resuspension factor approach has been extended by development of a time-dependent resuspension factor model which more accurately describes resuspension from aged sources. The most significant progress, however, has been the synthesis of soil erosion studies, dust flux measurements, and resuspended plutonium concentration measurements into an integrated approach which employs Healy's model of atmospheric transport and diffusion. The results are encouraging and this new approach may lead to a general resuspension model that is site-independent.

97. Phelps, P.L. and L.R. Anspaugh (1977). Development of Specialized Instruments and Techniques for Resuspension Studies. Transuranics in Natural Environments, Gatlinburg, Tennessee, Nevada Operations Office, Energy Research and Development Administration (NVO-178), p. 273-286.

Discussed is the development of specialized instruments and techniques for resuspension studies of plutonium and soil particle behavior. This includes the development of ultrahigh-volume air samplers which allow collection of adequate samples of plutonium at worldwide air concentration levels in two hours of sampling time. Also developed are samplers for measuring the fraction of particles moving in creep and saltation. Advanced optical methods for in situ sizing and counting of particles have also been employed.

98. Price, K.R. (1973). “A Review of Transuranic Elements in Soil, Plants and Animals.”J. Environ. Qual. 2:62-66.

The purpose of this review is to assemble the published information relevant to the distribution and fate of transuranic elements in soils, plants, and animals to identify areas in need of further study.

99. Rai, D., R.J. Serne and D.A. Moore (1980). "Solubility of Plutonium Compounds and Their Behavior in Soils." Soil Sci. Soc. Am. J. 44:490-495.

The solid compounds of $\mathrm{Pu}$ that may be present in soils have a specific solubility at equilibrium in a given weathering environment and could control the final concentration of $\mathrm{Pu}$ in the soil solution. The final concentration could, in turn, largely control the distribution of $\mathrm{Pu}$ in the environment. Therefore, knowledge of Pu compounds present in the soil and their solubility are necessary to predict the behavior of plutonium in the soil. 
100. Rhoads, W.A. (1976). "A Wise Solution of the Pu-Contaminated Lands Problem in Certain Parts of NTS may be to Isolate and Maintain Them Without Further Disturbances: A Position Paper." Studies of Environmental Plutonium and Other Transuranics in Desert Ecosystems (NVO-159), p. 165-180.

Rhoads proposes isolation, nonmanipulation, and protective nondisturbance may be an adequate treatment of $\mathrm{Pu}$-contaminated areas. This hypothetical treatment will, however, be restricted to those contaminated areas of the NTS which are within closed drainage basins as, for example, both Yucca and Frenchman basins. Some arguments may be applicable, however, to other nearby areas with similar adaphic and environmental conditions.

101. Rhodes, D.W. (1957). “Adsorption of Plutonium by Soil." Soil Science 84:465-470.

An experiment was conducted to investigate the adsorption of plutonium with soils. The data indicate the existence of a plutonium polymer that carries a positive charge that allows it to be taken up rapidly by soil. At a concentration of about $1 \times 10^{-4} \mathrm{M}$, plutonium polymerizes at $\mathrm{pH}$ levels between $\mathrm{pH} 1$ and $\mathrm{pH} 2$ and may be considered a hydroxide. The observed polymer was present at soil $\mathrm{pH}$ levels $>2$ with the possible exception of levels in the 9 to $12 \mathrm{pH}$ range. The attraction of the polymer to the soil would favor a high concentration of the $\mathrm{Pu}$ on the soil particles with little downward movement through the soil by rainfall leaching. This high concentration of Pu on soil particles also places the $\mathrm{Pu}$ in contact with the root structures of vegetation.

102. Ripple, S.R. (1992). "Looking Back: The Use of Retrospective Health Risk Assessments." Environ. Sci. Technol. 26(7):1270-1277.

Discussed are some of the retrospective health risk assessments underway at federal facilities and progress on a first-of-its-kind retrospective risk assessment currently being conducted for the Rocky Flats plant near Denver, Colorado. The approaches used in these studies to understand past health hazards are those that would be used to understand the hazards posed from the long-term operation of any large-scale industrial facility.

103. Romney, E.M., H.M. Mork and K.H. Larson (1970). "Persistence of Plutonium in Soil, Plants, and Small Mammals." Health Physics 19:487-491.

Plutonium fallout resultant from safety-shot activity had considerable heterogeneity in particle size distribution and the residual contamination became stabilized within a few weeks after deposition with minimal resuspension activities except for mechanical disturbances or extreme wind gusts. Immediate downward movement of particles into the soil was noted. Significant particle movement occurs with rain, wind and stream activities. Initial plant uptake of Pu through the root system was minimal with increasing amounts present after following years. The type of chelate present in the plant and soil is a significant factor in Pu uptake. Accumulation of Pu in small mammals was highest in bone tissue with considerable amounts found in lung and gastrointestinal tracts. 
104. Romney, E.M. and J.J. Davis (1972). "Ecological Aspects of Plutonium Dissemination in Terrestrial Environments." Health Physics 22:551-557.

Fallout conditions having high concentrations in the air would create an immediate or acute inhalation hazard to persons in the area. The residual surface contamination is only hazardous if resuspension occurs. Indigenous animals would be exposed through inhalation and ingestion. Exposure by inhalation was shown to decrease with time while ingestion rates remained fairly constant. Exposure would be worse for animals that live, dig, or bathe in contaminated soils. Animals investigated 2.8 and 10.8 years after safety-shot soil contamination still demonstrated the presence of plutonium in lung tissue. Plant uptake was observed to be minimal. The downward movement of $\mathrm{Pu}$ into the soil is attributed to fine particles moved by the flow of infiltrating water or by mechanical means. Cleanup of contaminated soils can pose a threat by creating soil disturbances that initiate resuspension, and may be best left alone.

105. Romney, E.M., A. Wallace, R.O. Gilbert, S.A. Bamberg, J.D. Childress, J.E. Kinnear and T.L. Ackerman (1974). "Some Ecological Attributes and Plutonium Contents of Perennial Vegetation in Area 13 (NAEG Vegetation Studies)." Dynamics of Plutonium in Desert Environments, pp. 91-106.

This interim report investigates the relationship of $\mathrm{Pu}$-contaminated soils to the levels of $\mathrm{Pu}$ contamination found in plants growing in that soil at a safety-shot site at the NTS. Preliminary results indicate consistency in the amounts of $\mathrm{Pu}$ in similar plant species, while different species had varying levels. The relationship between the levels of $\mathrm{Pu}$ in the soil to that of the vegetation varied and was not found to be statistically acceptable. Vegetation with hairy or sticky surfaces had higher $\mathrm{Pu}$ levels due to the entrapment and holding of particles afforded by resuspension.

106. Romney, E.M., E.H. Essington, E.B. Fowler, T. Tamura and R.O. Gilbert (1983). Plutonium in the Desert Environment of the NTS and the Tonopah Test Range. Environmental Research on Actinide Elements, CONF-841142, Hilton Head, South Carolina, U.S. Department of Energy, p. 121-130.

Follow-up studies were conducted by the NAEG at safety-shot sites to determine the distribution in soils and the availability to animal and plants of plutonium after residence times of 10 to 20 years.

Soil profile studies show that more than $95 \%$ of the Pu dispersed had remained in the top $5 \mathrm{~cm}$ of the soil in undisturbed areas; only trace amounts had moved to a depth of $25 \mathrm{~cm}$, except where the soil had been mechanically disturbed. Significant amounts had been redistributed into blow-sand mounds formed underneath clumps of vegetation. That redistribution should be expected because the contaminant was associated primarily with coarse silt $(20-50 \mu \mathrm{m})$ and fine sand $(50-125 \mu \mathrm{m})$ particle-size fractions. Resuspension factors were calculated that varied from $9.1 \times 10^{-11} \mathrm{~m}^{-1}$ to $5.4 \times 10^{-9} \mathrm{~m}^{-1}$, with geometric mean and arithmetic averages of $2.9 \times 10^{-10} \mathrm{~m}^{-1}$ and $6.8 \times 10^{-10}$ $\mathrm{m}^{-1}$, respectively; however, the plutonium essentially remained in place when the soil surface was left undisturbed.

107. Rosebury, K.D. and R. Zimmer (1985). Dust Controls at Hazardous Waste Sites. Hazardous Waste Engineering Research Laboratory, Office of Research and Development, U.S. Environmental Protection Agency, Cincinnati, Ohio.

The intent of this handbook is to identify sources of fugitive dust and the methods, applications, products and estimated costs of its control. 
108. Sehmel, G.A. (1976). Plutonium and Tracer Particle Resuspension: An Overview of Selected Battelle-Northwest Experiments. Transuranics in Natural Environments, Gatlinburg, Tennessee, Nevada Applied Ecology Group, Energy Research and Development Administration (NVO-178), p. 181-210.

Particle resuspension rates are a function of at least wind speed and mechanical disturbances. Mechanical disturbances, such as vehicular traffic or a man walking, can cause high local resuspension rates. Average wind resuspension rates from a local area could be less important per unit area than local mechanical disturbance resuspension. If one were to compare relative resuspension from wind-caused and mechanical disturbances, one would need to know the total surface contamination area for wind resuspension versus small localized surface contamination levels for mechanical disturbance resuspension rates.

109. Sehmel, G.A. (1978). "Airborne Plutonium-239 and Americium-241 Transport Measured From the 125-M Hanford Meteorological Tower." Selected Environmental Plutonium Research Reports of the NAEG (NVO-192), Vol. 2, p. 707-723.

Airborne plutonium-239 and americium-241 concentrations and fluxes were measured at six heights from 1.9 to $122 \mathrm{~m}$ on the Hanford meteorological tower. The data show plutonium-239 was transported on nonrespirable and "small" particles at all heights. In controlled areas, plutonium-239 transport occurred to at least a 30-m height.

110. Sehmel, G.A. (1980). "Transuranic and Tracer Simulant Resuspension." Transuranic Elements in the Environment, p. 236-285.

Plutonium resuspension rates are summarized for experiments conducted at Rocky Flats for winds blowing from off-site onto the Hanford Reservation. In each case, plutonium was shown by increased airborne plutonium concentrations as a function of either wind speed or as compared with fallout levels. Plutonium was transported on both respirable and nonrespirable airborne-soil particles.

Airborne concentrations of ${ }^{239} \mathrm{Pu},{ }^{241} \mathrm{Am},{ }^{238} \mathrm{Pu},{ }^{137} \mathrm{Cs}$, and ${ }^{90} \mathrm{Sr}$ increased as a function of wind speed to one to the sixth power for off-site resuspension increased as a power function of wind speed. Above a wind speed of about $5 \mathrm{~m} / \mathrm{sec}$, airborne plutonium concentrations increased with wind speed to the third to fifth power. In controlled source experiments, tracer-particle resuspension rates increase with about the fifth power of wind speed. The fifth power is similar to off-site plutonium resuspension. The tracer particles had a mean diameter of $8 \mu \mathrm{m}$.

111. Sehmel, G.A. (1983). Transuranic Resuspension. Environmental Research on Actinide Elements, Hilton Head, South Carolina, U.S. Department of Energy, p. 157-192.

The objective of this article is to summarize plutonium and americium resuspension research conducted by the Pacific Northwest Laboratory from 1977-1983.

Concentrations of $\mathrm{Pu}$ and $\mathrm{Am}$ were examined as a function of aerodynamic particle diameter, sampling height, wind speed increments, and wind direction increments. The following results are discussed: airborne radionuclide concentrations, $u \mathrm{Ci} / \mathrm{cm}^{3}$ of sampled air; radionuclide activity densities, $u \mathrm{Ci} / \mathrm{g}$ of airborne solids; airborne plutonium fluxes $\left(u \mathrm{Ci} / \mathrm{m}^{2} \mathrm{~d}\right),{ }^{241} \mathrm{Am} /{ }^{239,240} \mathrm{Pu}$ activity ratios $\left(u \mathrm{Ci}^{241} \mathrm{Am}\right) /\left(u \mathrm{Ci}^{239,240} \mathrm{Pu}\right)$, and airborne solid concentrations $u \mathrm{~g} / \mathrm{m}^{3}$ of sampled air. 
112. Shinn, J.H. and L.R. Anspaugh (1975). "Resuspension-New Results in Predicting the Vertical Dust Flux." The Radioecology of Plutonium and Other Transuranics in Desert Environments, Nevada Applied Ecology Group Progress Report (NVO-153), p. 207-213.

The key to assessing resuspension of $\mathrm{Pu}$ by wind from aged deposits and other hazardous particles is to predict the vertical flux from the host dust particles. This approach has been utilized in studying both short- and long-term resuspension from the GMX location of the NTS. Dust flux is defined as the net loss of mass per unit ground area per unit time. Usually, computations can be simplified when the dust flux occurs from a broad, flat area much larger than the area of original deposit of contaminant. If this is the case, then it is possible to show that the resuspension of Pu from the area of the deposit is determined wholly by the vertical dust flux and the horizontal geometry of the contaminated area.

113. Shinn, J.H. (1976). Observations of Dust Flux in the Surface Boundary Layer for Steady and Nonsteady Cases. Atmospheric-Surface Exchange of Particulate and Gaseous Pollutants, Richland, Washington, CONF-740921, p. 625-637.

In this article, dust flux measurements by the eddy-correlation method are compared for several cases of strong steady winds and intermittent gust fronts. The calculation of flux for analysis and evaluation of health hazards due to resuspension of respirable particulates is simplified by parameterization to friction velocity and erodibility. The dust concentration is shown to sometimes vary with the sixth power of the wind speed. A parametric vertical dust-flux model is proposed which is general for dry and unvegetated areas. There is utility in the parametric model for assessment of health hazards by resuspension, but it is far from universal.

114. Shinn, J.H. (1976). Estimation of Aerosol Plutonium Transport by the Dust-Flux Method: A Perspective of Application on Detailed Data. Transuranics in Natural Environments, Gatlinburg, Tennessee, Nevada Applied Ecology Group and Energy Research and Development Administration (NVO-178), p. 171-180.

Two methods of dust flux measurements which have been utilized to estimate aerosol plutonium deposition and resuspension are discussed. The methods were found to be sufficiently detailed to permit parameterization of dust flux to the erodibility of the soil, and a seventh-power dependency of dust flux (or plutonium flux) to wind speed was observed in worst-case conditions.

The eddy-correlation method is technically more difficult, requires high-speed data acquisition, and requires an instrument response time better than one second, but the eddy-correlation method has been shown feasible with new fast-response sensors, and it is more useful in limited areas because it can be used as a probe. The flux-gradient method is limited by critical assumptions and is more bulky, but the method is more commonly used and accepted. The best approach is to use both methods simultaneously. 
115. Shinn, J.H., D.N. Homan and C.B. Hoffman (1986). A Summary of Plutonium Aerosol Studies: Resuspension at the Nevada Test Site. Lawrence Livermore National Laboratory, Environmental Sciences Division, Livermore, California.

Four sites at the NTS were investigated for the plutonium-aerosol flux caused by wind erosion, the plutonium-aerosol size distributions, and trends in plutonium-aerosol concentration as affected by season and by disturbance. The results are useful for estimating the extent of human exposure from inhalation of alpha-emitting particles, for determining the plutonium-aerosol source term needed to calculate long-term transport, and for estimating the time necessary for wind erosion to carry a significant amount of soil away. The authors used meteorological flux-gradient techniques supplemented by a portable, floorless wind tunnel to control stress on the soil surface.

The authors feel that safety-shot tests will need to be examined on a case-by-case basis because results vary widely. Secondly, the seasonal peak of alpha radioactivity does not coincide with the seasonal peak of suspended soil. This result leads to the conclusion that the sites should be monitored year-round. Third, disturbance preferentially releases contaminated particles, thereby increasing the enhancement factor, but such disturbance does not effect particle diameter.

116. Shinn, J.H., D.N. Homan and C.B. Hoffman (1989). "Results of a Cleanup and Treatment Test at the Nevada Test Site: Evaluation of Vacuum Removal of Pu-Contaminated Soil." Health Physics (57):771-779.

The experiment consisted of removing contaminated soils from the NTS with a large truck-mounted vacuum cleaner. Results show that this method is effective, relatively easy, and safe for equipment operators. With four passes of the truck-mounted vacuum, $92 \%$ of the $\mathrm{Pu}$ was removed and resuspension rates were reduced by more than $99 \%$.

The ecological impact was severe. Sites vacuumed can suffer severe soil erosion, but resprouted shrubs and natural reseeding restored sparse vegetation within two years. The effect on small animals and their habitats was dramatically negative.

117. Sill, C.W. (1971). The Particle Problem as Related to Sample Inhomogeneity. Proceedings of Environmental Plutonium Symposium, Los Alamos Scientific Laboratory, University of California, Los Alamos, New Mexico. National Technical Information Service, U.S. Department of Commerce, Springfield, Virginia.

The activity of $\mathrm{N}$ spherical particles of pure ${ }^{239} \mathrm{PuO}^{2}$ is $0.721 \mathrm{ND}^{3} \mathrm{dpm}$ where $\mathrm{D}$ is the diameter of the particle in microns. The ${ }^{239} \mathrm{PuO}^{2}$ particle activity is proportional to the third power of the diameter. A tenfold increase in the diameter of a particle gives a thousandfold increase in activity; therefore, one single large particle can contribute as much activity as a thousand smaller ones with one-tenth the diameter. 
118. Skidmore, E.L. (1976). A Wind Erosion Equation: Development, Applications, Limitations. Atmosphere-Surface Exchange of Particulate and Gaseous Pollutants (1974), CONF-740921, Richland, Washington, ERDA Symposium Series, p. 452-463.

This paper reviews briefly the development of a wind erosion equation to delineate major causes of wind erosion. Soil loss in tons per acre year is predicted as a function of field width, soil erodibility, soil roughness, climate, and vegetation. Soil erodibility decreases as the percentage of nonerodible soil fractions exceeding $0.84 \mathrm{~mm}$ increases. Kuugh surfaces are less erodible than smooth ones. The climatic factor is an index of the influence of moisture content in the surface soil particles and the average wind speed on the rate soil is moved by the wind. The rate at which soil moves increases with distance downfield until maximum flow is reached. Fine-textured, standing residues reduce wind erosion more than do coarse-textured or flattened residues. Some sources of error and limitations of the equation are discussed.

119. Slinn, W.G.N. (1976). "Formulation and a Solution of the Diffusion-DepositionResuspension Problem." Atmos. Environ. 10:763-768.

Formulating and solving the diffision-deposition-resuspension problem is of interest for assessing the potential environmental and health impacts of releases of radioactive contaminants. The reformulation of the diffusion-deposition-resuspension problem starts from convective diffusion equations for the air and surface concentrations, coupled by two interfacial boundary conditions. A number of the available parameterizations of the boundary conditions are reviewed and interrelated. Time and $\mathbf{x}$-dependent solutions are obtained for the vertically averaged air and surface concentrations, combined with rates of resuspension and deposition, and the influence of $y$ and $\mathrm{z}$ diffusion are estimated.

120. Smith, W.J., F.W. Whicker and H.R. Meyer (1982). "Review and Categorization of Saltation, Suspension, and Resuspension Models." Nuclear Safety (23):685-699.

Fifteen mathematical models for estimating the entrainment of particles by wind are reviewed and categorized. A description of the origin and intended application of each model and a brief review of the formulation and parameterization are given. Important assumptions, limitations, and features of each technique is noted.

121. Stockton, P.H. and D.A. Gillette (1990). "Field Measurement of the Sheltering Effect of Vegetation on Erodible Land Surfaces." Land Degradation and Rehabilitation 2:77-85.

The partitioning of wind momentum between that absorbed by vegetation and that absorbed by loose soil lying among vegetation may be calculated by determining threshold friction velocities for the bare soil without vegetation present and for the vegetated soil along with the fraction of bare soil to total area. Threshold friction velocities were obtained by using devices that record the onset of particle movement and wind tunnel experiments. 
122. Tamura, T. (1974). "Distribution and Characterization of Plutonium in Soils from Nevada Test Site." The Dynamics of Plutonium in Desert Environments (NVO-142), p. 29-42.

Three surface soil samples contaminated with plutonium from safety-shot sites at the NTS were analyzed for total plutonium content, plutonium distribution in different particle-size fractions, and leachability by $\mathrm{HNO}_{3}$. The highest concentration of plutonium was in the coarse silt fraction, and $76 \%$ of the plutonium was in the silt and clay fractions. In the desert pavement soil, the highest plutonium concentration was also in the very fine sand size fraction; the silt and clay size fractions contained $16 \%$ of the total plutonium. Leaching with $8 \mathrm{M} \mathrm{HNO}_{3}$ for one-half hour at $93^{\circ} \mathrm{C}$ revealed that $91 \%$ of the plutonium was leached from the microplot soil, $80 \%$ from the desert pavement soil, and 65\% from the blow sand.

Densicy gradient separation of silt and clay fractions revealed that the plutonium in the silt fraction was associated with particles greater than $2.8 \mathrm{~g} / \mathrm{cc}$ (heaviest fraction), whereas in the clay fraction the plutonium was in the 2.1 to $2.2 \mathrm{~g} / \mathrm{cc}$ fraction. This suggests that the plutonium in the silt size fraction is probably present as an oxide, whereas in the clay size fraction it may be a polymeric form adsorbed on lighter clay materials.

123. Tamura, T. (1975). "Characterization of Plutonium in Surface Soils from Area 13 of the Nevada Test Site." The Radioecology of Plutonium and Other Transuranics in Desert Environments (PUB/NVO-153), p. 27-41.

Total plutonium was determined in nine surface soil samples $(0-5 \mathrm{~cm})$ from Area 13 at the NTS. Particle-size segregation was performed, and each particle-size fraction of seven samples was analyzed for plutonium. The coarse silt fraction $(53-20 \mu \mathrm{m})$ contained the highest percentage of plutonium in the soil (about $65 \%$ ). Evidence of erosional translocation of plutonium was observed in one sample.

Tests with eight molar nitric acid showed that about $13 \%$ of the plutonium was leached from the soil samples and in $0.1 \mathrm{M}$ citric acid, about $1 \%$ of the plutonium was extracted.

124. Tamura, T. (1975). "Distribution and Chemical Characterization of Plutonium in Soils from the Nevada Test Site." J. Environ. Qual. 7(2).

This report discusses results obtained from three selected surface-soil samples $(0-3 \mathrm{~cm}$ depth) from two safety-shot areas at the NTS. The samples were analyzed for total plutonium content, plutonium distribution in different particle sizes, and leachability by $\mathrm{HNO}_{3}$. Analyses revealed that the plutonium distribution was relatively uniform. The highest concentration of plutonium (47\% total $\mathrm{Pu})$ in the microplot soil was in the coarse silt $(53-20 \mu \mathrm{m})$ fraction, and $76 \%$ of the Pu was in the silt (53-2 $\mu \mathrm{m}$ diameter) and clay ( $<2 \mu \mathrm{m}$ diameter). In the desert pavement soil, the highest concentration ( $47 \%$ of the total) was in the very fine sand (125-53 $\mu \mathrm{m}$ diameter) fraction; the silt and clay sizes contained $36 \%$ of the total plutonium. In the blow-sand sample, the highest concentration (39\% of the total) was also in the very fine sand size; the silt and clay sizes contained $16 \%$ of the total plutonium.

125. Tamura, T. (1976). "Plutonium-Soil Association: A Summary." Selected Environmental Reports of the NAEG (NVO-166), Voi. 1, p. 245-252.

This report summarizes the research from 1974 to 1978 on plutonium-soil association in the safety-shot areas of the NTS. A recommendation is made to initiate clean-up trial operations at the NTS for the purpose of providing information on equipment development, testing and evaluation of soil sealing, logistics of operation, and cost-effectiveness of the operation. 
126. Tamura, T. (1976). "Plutonium Association in Surface Soils of Area 13: A Progress Report." Studies of Environmental Plutonium and Other Transuranics in Desert Ecosystems (NVO-159), p. 5-16.

Analyses of three soil samples taken along a north-south transect in Area 13 gave mean plutoniun values of 324,132 , and $166 \mathrm{dpm} / \mathrm{g}$ for the samples taken at 1,910,2,770 and 3,665 feet, respectively, from ground zero. In all three samples, more than $65 \%$ of the plutonium was in the 53-20 $\mu \mathrm{m}$ size fraction.

Mound samples contained a high fine sand content and the plutonium content was highest in the medium and coarse silt sizes. Although the field survey instrument (FIDLER) recorded a higher reading for the sample under shrubbery as compared with nonvegetated soil, the analysis showed that the nonvegetated soil had a higher plutonium content in the $0-5 \mathrm{~cm}$ depth.

127. Tamura, T. (1976). "Physical and Chemical Characteristics of Plutonium in Existing Contaminated Soils and Sediments." Transuranium Nuclides in the Environment, p. 213-229.

Plutonium from three safety-shot sites at the NTS has been studied to provide information necessary in understanding its behavior. Plutonium in soils from the NTS was predominantly associated (50-75\%) with the coarse-silt $(53-20 \mu \mathrm{m})$ fraction. The coarse-silt fraction was further segregated by density gradient zonal centrifugation; the $\mathrm{Pu}$ in the sample from a bare soil ranged from $60-85 \%$ in 'heavy' mineral fraction $\left(>2.9 \mathrm{~g} / \mathrm{cm}^{3}\right)$ suggesting the presence of oxide forms. The $\mathrm{Pu}$ in a sandy mound taken beneath shrubbery occurred predominantly (80-95\%) in a lighter fraction (2.5-2.7 g/cm ${ }^{3}$ ) associated with feldspar. Soil extraction of NTS Pu with $0.1 \mathrm{M}$ citric acid solution showed very low solubility (about $1 \%$ ).

128. Tamura, T. (1977). Plutonium Association in Soils. Transuranics in Natural Environments, Gatlinburg, Tennessee, Nevada Applied Ecology Group, Energy Research and Development Administration (NVO-178), p. 97-114.

This paper reviews the adhesion of plutonium to soil and sediment particles, plutonium size characteristics involved with this adhesion, particle-size association with various soil types, and resuspension activity factors. The association of plutonium with the soil particle sizes is reviewed and a soil-plutonium index is derived to permit comparison of the potential transfer to man via the inhalation pathway.

Once plutonium comes in contact with soil and sediment particles, it becomes firmly attached to the host particle. The strong attraction is exemplified by the high absorption coefficients exhibited by soils and sediments in laboratory studies with soils. Studies of the size association of plutonium on the NTS showed that most of the plutonium was associated with soil particles greater than $44 \mu \mathrm{m}$ in diameter and the association was primarily with the coarse-silt $(50-20 \mu \mathrm{m})$ and fine-sand $(125-50 \mu \mathrm{m})$ sizes.

129. Tamura, T. (1977). "Plutonium Distribution in a Desert Pavement-Desert Mound." Environmental Plutonium on the Nevada Test Site and Environs (NVO-171), p. 1-16.

This report presents data on plutonium distribution in a desert pavement-desert mound soil system in Area 11 of the NTS.

Analyses of plutonium in the desert-pavement sample showed that $95 \%$ of the activity is in the surface layer $(0-2.5 \mathrm{~cm})$. In the desert-mound sample, $60 \%$ of the activity is in the surface layer. Significant amounts of plutonium occur down to the $7.5-\mathrm{cm}$ depth, but there is a possibility that this depth distribution is due to the method of sampling. 
The soil particle-size classes with the highest plutonium activity are the coarse silt (53-20 $\mu \mathrm{m})$ in the desert pavement and the medium silt $(20-5 \mu \mathrm{m})$ in the desert mound. The high activity associated with soil particles less than $20-\mu \mathrm{m}$ particle size in the desert mound sample suggests that the fine-particle activity is from a source close to ground zero. Density gradient segregation of the silt fractions in the surface layer showed that the highest activity is in the heaviest fraction (greater than $2.9 \mathrm{~g} / \mathrm{cm}^{3}$ density).

130. Travis, J.R. (1970). A Model for Predicting the Redistribution of Particulate Contaminants from Soil Surfaces. Atmosphere-Surface Exchange of Particulate and Gaseous Pollutants (1974), Richland, Washington, ERDA Symposium Series.

This article discusses a computerized model to describe the redistribution of wind-eroding soil-contaminant mixtures.

131. Wallace, A. and E.M. Romney (1976). "Has the Work of the NAEG at the Safety Shot Sites Come to a Logical Conclusion?" (NVO-166), p. 121-125.

The five years of study by the NAEG of Pu and other radionuclides at the old safety-shot sites in Nevada have provided much environmental information, especially as relates to the nature, distribution, persistence, and amount of the contaminants present. There is, however, much important information on resuspension and on biologic, edaphic, and hydrologic reaction mechanisms which yet need to be obtained to help resolve many of the questions concerning dissemination of transuranic elements into the natural environment. Several cases in point are discussed as examples.

132. Wessman, R.A. and L. Leventhal (1976). Historical Review of Transuranic Analytical Methodology. Transuranics in Natural Environments, Gatlinburg, Tennessee, Nevada Applied Ecology Group, Energy Research and Development Administration (NVO-178), p. 545-574.

The methods used for the analysis of the transuranic elements neptunium, plutonium, americium, and curium are reviewed. Attention is given to those procedures suitable for low-level environmental and biological assessment. The preparation of such samples, derived from a variety of sources and incorporated in different masses and volumes of soils, water, vegetation, and bioiogical matrices is described. A comprehensive discussion of matrix dissolution and equilibrium techniques indicates that complete dissolution employing tracer techniques is to be preferred. Sample preparation techniques for radiometric assay, such a stippling, evaporation and plating, are reviewed. Past and current methods for the transuranic alpha, beta, and gamma emitters are reviewed. 


\section{DISTRIBUTION}

\section{U.S. Department of Energy}

Gylan Allen

Test Operations Division

Nevada Operations Office

U.S. Dept. of Energy

P.O. Box 98518

Las Vegas, NV 89193-8518

\section{Doug Duncan}

Hydrology Program Manager

Office of Environmental Restoration \& Waste

Management

Nevada Operations Office

U.S. Dept. of Energy

P.O. Box 98518

Las Vegas, NV 89193-8518

Don Elle, Director

Environment Protection Division

Nevada Operations Office

U.S. Dept. of Energy

P.O. Box 98518

Las Vegas, NV 89193-8518

Joseph N. Fiore, Acting Asst. Mgr.

Office of Environmental Restoration \& Waste

Management

Nevada Operations Office

U.S. Dept. of Energy

P.O. Box 98518

Las Vegas, NV 89193-8518

Joseph H. Kitchen

Technology and Program Management Division

Nevada Operations Office

U.S. Dept. of Energy

P.O. Box 98518

Las Vegas, NV 89193-8518

Steve Lawrence

Environmental Restoration Division

Nevada Operations Office

U.S. Dept. of Energy

P.O. Box 98518

Las Vegas, NV 89193-8518
John S. Ledbetter

Contracts Division

Nevada Operations Office

U.S. Dept. of Energy

P.O. Box 98518, MS 505

Las Vegas, NV 89193-8518

Steve Leedom

Test Operations Division

Nevada Operations Office

U.S. Dept. of Energy

P.O. Box 98518

Las Vegas, NV 89193-8518

Steve Mellington, Director

Environmental Restoration Division

Nevada Operations Office

U.S. Dept. of Energy

P.O. Box 98518

Las Vegas, NV 89193-8518

Technical Information Resource Center

Nevada Operations Office

U.S. Dept. of Energy

P.O. Box 98518

Las Vegas, NV 89193-8518

Richard Pearl

Environmental Protection Division

Nevada Operations Office

U.S. Dept. of Energy

P.O. Box 98518

Las Vegas, NV 89193-8518

\section{U.S. Department of Defense}

David Bedsun

Defense Nuclear Agency

U.S. Department of Defense

P.O. Box 98539

Las Vegas, NV 89193-8539

Lawrence Livermore National Laboratory

Greg Nimz

Lawrence Livermore National Laboratory

P.O. Box 808, MS L233

Livermore, CA 94550 
Los Alamos National Laboratory

Joe Thompson

Los Alamos National Laboratory

INC-11, MS J514

P.O. Box 1663

Los Alamos, NM 87545

\section{U.S. Geological Survey}

Virginia Glanzman

U.S. Geological Survey

Box 2506, MS 913

Denver Federal Center

Denver, CO 80225

Randy Laczniak

U.S. Geological Survey

Water Resources Division

6770 S. Paradise Rd.

Las Vegas, NV 89119

Paul Orkild

U.S. Geological Survey

Box 2506, MS 913

Denver Federal Center

Denver, CO 80225

Doug Trudeau

U.S. Geological Survey

Water Resources Division

6770 S. Paradise Rd.

Las Vegas, NV 89119

\section{Desert Research Institute}

Roger Jacobson

Desert Research Institute

Water Resources Center

P.O. Box 19040

Las Vegas, NV 89132-0040

Marjory Jones

Desert Research Institute

Water Resources Center

P.O. Box 60220

Reno, NV 89506-0220
Forest L. Miller, Jr.

Desert Research Institute

Water Resources Center

P.O. Box 19040

Las Vegas, NV 89132-0040

Reynolds Electrical \& Engineering Co.

Martha DeMarre

Chief, Document Research Section

Health Protection Dept.

Reynolds Electrical \& Engineering Co.

P.O. Box 98521

Las Vegas, NV 89193-8521

Brian Dozier

Reynolds Electrical \& Engineering Co.

2501 Wyandotte

Mercury, NV 89102

\section{LIBRARIES}

Archives

Getchell Library

University of Nevada, Reno

Beverly Carter

MacKay School of Mines Library

University of Nevada, Reno

Stead Library

Desert Research Institute

Reno, Nevada

Southem Nevada Science Center

Water Resources Center, Library

P.O. Box 19040

Las Vegas, NV 89132-0040

Document Section, Library

University of Nevada, Las Vegas

4505 Maryland Parkway

Las Vegas, NV 89154

Annie Kelley

State Documents Department

Nevada State Library

Capitol Complex

Carson City, NV 89710 
Water Resources Research Archives University of California

Room 40, North Gate Hall

Berkeley, CA 94720

International Technology Corp.

Rick Waddell

Geotrans

c/o IT

4330 Valley View

Suite 112

MS-439

Las Vegas, NV 89103

Joe Yeasted

International Technology Corp.

Southem Nevada Science Center

P.O. Box 19040

Las Vegas, NV 89132-0040

University of Cincinnati

Roy Eckart

University of Cincinnati

Department of Mechanical, Industrial and Nuclear Engineering

598 Rhodes Hall

ML-0072

Cincinnati, OH 45221-0072
Eugene Rutz

University of Cincinnati

Department of Mechanical, Industrial and Nuclear Engineering

598 Rhodes Hall

ML-0072

Cincinnati, OH 45221-0072

Talaat Ijaz

University of Cincinnati

Department of Mechanical, Industrial and Nuclear Engineering

598 Rhodes Hall

ML-0072

Cincinnati, $\mathrm{OH}$ 45221-0072 

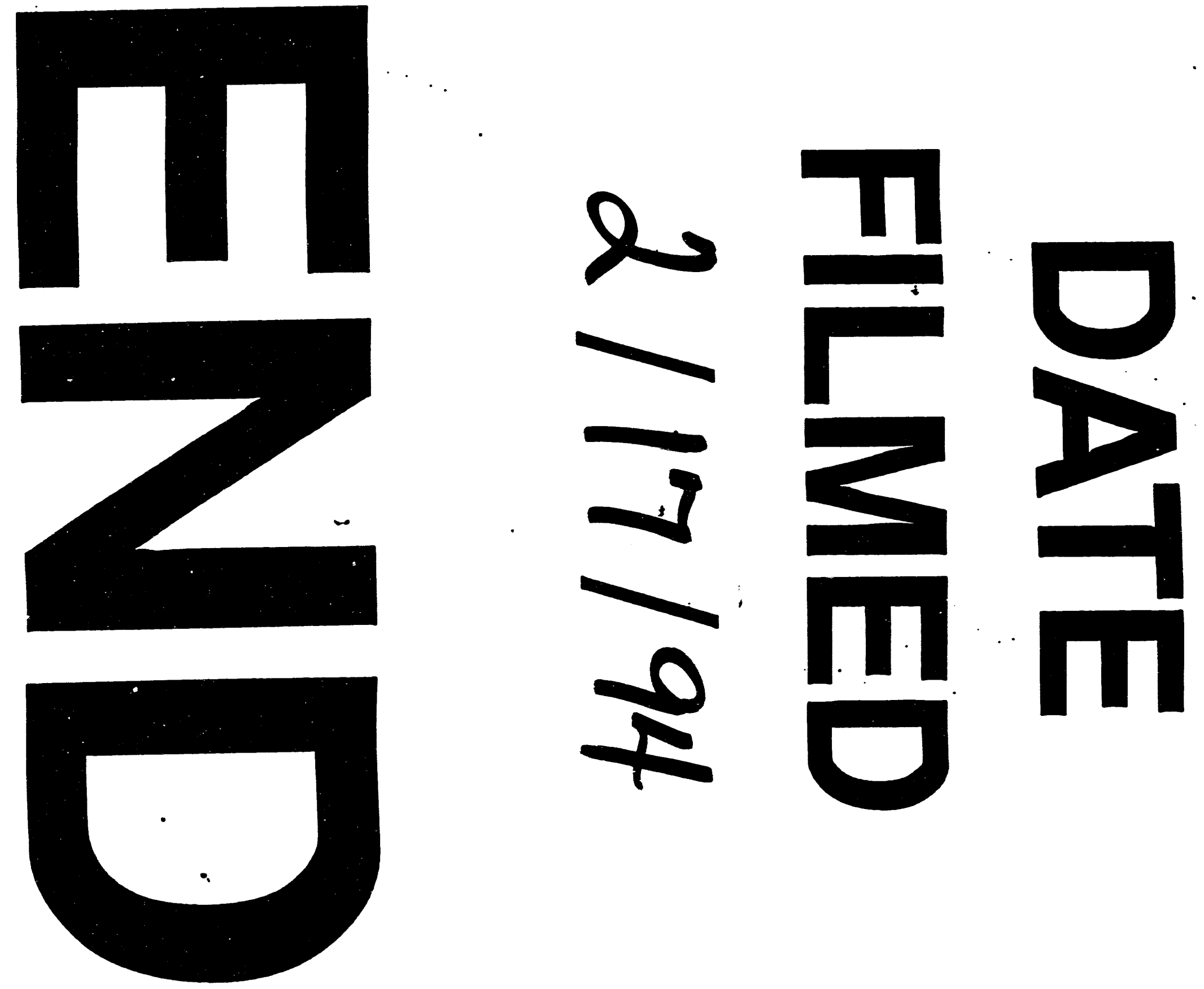


$$
\text { (2) }
$$

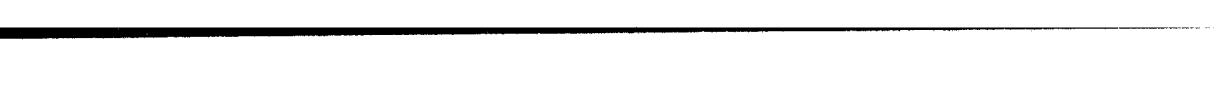

